Florida International University

FIU Digital Commons

\title{
The Historical Evolution of the A.M.E. Church: Social Intervention to Advance Blacks Socio-Economic Position
}

Jasmin N. Graham

jgrah025@fiu.edu

Follow this and additional works at: https://digitalcommons.fiu.edu/etd

Part of the Christian Denominations and Sects Commons, Christianity Commons, History of Christianity Commons, New Religious Movements Commons, Practical Theology Commons, and the Religious Education Commons

\section{Recommended Citation}

Graham, Jasmin N., "The Historical Evolution of the A.M.E. Church: Social Intervention to Advance Blacks Socio-Economic Position" (2019). FIU Electronic Theses and Dissertations. 4018.

https://digitalcommons.fiu.edu/etd/4018

This work is brought to you for free and open access by the University Graduate School at FIU Digital Commons. It has been accepted for inclusion in FIU Electronic Theses and Dissertations by an authorized administrator of FIU Digital Commons. For more information, please contact dcc@fiu.edu. 


\title{
FLORIDA INTERNATIONAL UNIVERSITY
}

Miami, Florida

THE HISTORICAL EVOLUTION OF THE A.M.E. CHURCH: SOCIAL INTERVENTION TO ADVANCE BLACKS SOCIO-ECONOMIC POSITION

\author{
A thesis submitted in partial fulfillment of \\ the requirements for the degree of \\ MASTER OF ARTS \\ in \\ RELIGIOUS STUIDES
}

by

Jasmin N. Graham 
To: Dean John F. Stack, Jr.

Steven J. Green School of International Public Affairs

This thesis, written by Jasmin N. Graham, and entitled The Historical Evolution of the A.M.E. Church: Social Intervention to Advance Blacks Socio-Economic Position, having been approved in respect to style and intellectual content, is referred to you for judgment.

We have read this thesis and recommend that it be approved.

Ana Maria Bidegain

Albert Wuaku

Erik Larson, Major Professor

Date of Defense: March 28, 2019

This thesis of Jasmin N. Graham is approved.

Dean John F. Stack

Steven J. Green School of International Public Affairs

Andres G. Gil

Vice President for Research and Economic Development

And Dean of the University Graduate School

Florida International University, 2019 


\section{ACKNOWLEDGMENTS}

I have benefited from the support of many individuals in the conception and writing of this thesis. I owe much appreciation to Dr. Larson for his enduring assistance in helping me realize my potential and then motivating me to meet it. The help he provided as not only a mentor, but also as my life coach has placed me permanently in his debt. I am forever grateful for his patience and guidance.

My sincere gratitude is extended to my mother who continued through the years to encourage me and helped sustain me during the completion of this thesis. Her faith motivated me to pursue this goal of mine no matter how arduous the process. Her constant faith a constant reminder that I could accomplish anything I put my mind to. There were many times that her faith in my ability to complete my thesis surpassed my own.

Finally, I am truly thankful for my loving partner, Peter, who supported me through the entire process. His silent and patient way made room for me to do what I needed to do in order to successfully complete my goal. His optimism and tendency to never complain or fret were invaluable qualities in getting me through this process. I am grateful for the many times that he listened to me talk incessantly about new found information pertaining to my work early in the morning and late at night - not once seeming disinterested. His patience, understanding, and ability to graciously accept the demands that were placed on my time fortified me.

I will always be grateful to these three for their support and guidance. 


\title{
ABSTRACT OF THE THESIS \\ THE HISTORICAL EVOLUTION OF THE A.M.E. CHURCH- SOCIAL INTERVENTION TO ADVANCE BLACKS SOCIO-ECONOMIC POSITION
}

\author{
by
}

\author{
Jasmin N. Graham \\ Professor Erik Larson, Major Professor
}

Though it is well documented that the African Methodist Episcopal Church (AMEC) has been greatly involved in Black's educational attainments; there is limited documentation on the connection between the educational efforts of the AMEC and its effect on the financial stability of Blacks. The objective of the study is to evaluate the AMEC's tendency to intervene on behalf of its community. Tracing the different socioeconomic initiatives of the AMEC through the lenses of education from the late $18^{\text {th }}$ century to the present has revealed the various meanings of the term freedom and how the church has adapted to acquire it.

Findings suggest that the AMEC remains active in ensuring the socio-economic betterment of the Black community. Finally, findings indicate that the church has successfully met the contemporary needs of the Black community; though there still remains a need for an economic program that directly educates Blacks on financial literacy. 


\section{TABLE OF CONTENTS}

CHAPTERS

PAGE

I. BACKGROUND OF THE STUDY

Introduction..............................................................

Problem

Statement.................................................................6

Research

Questions..................................................................

Research

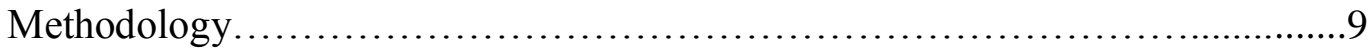

Research

Objective............................................................10

Relevance of

Study....

II. THE ORIGIN AND DEVELOPMENT OF THE A.M.E. CHURCH AND ITS EDUCATIONAL INITIATIVES

Methodist Episcopal

Church....

The Methodist Episcopal Church and Social

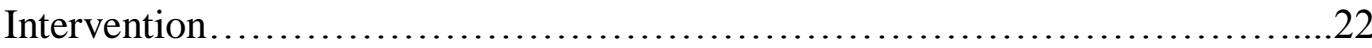

The Black Church and

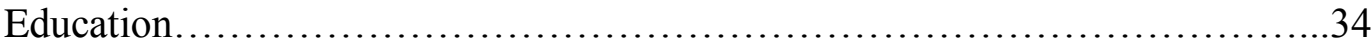

Pioneers of Education within the

AMEC

The Branches of

Education... 67

Common

Schools .71

Sunday

Schools

Theological

Centers................................................................. 73

Higher Education................................................. 75

Hampton-Tuskegee Model versus Liberal

Education

III. THE CONTEMPORARY A.M.E.C AND SOCIO-ECONOMIC

BETTERMENT Modern Initiatives.......................................87

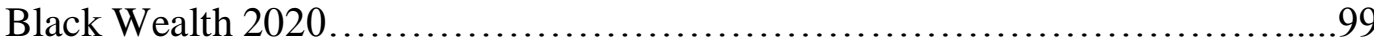

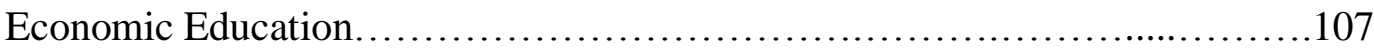




\section{CONCLUSION}

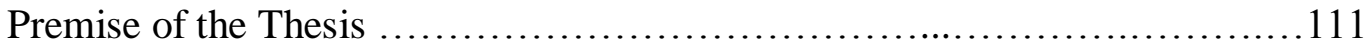

Findings................................................................ 14

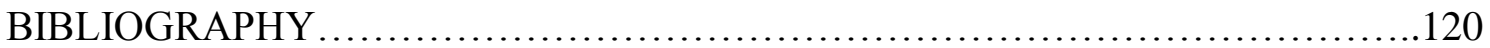




\section{BACKGROUND OF THE STUDY}

\section{Introduction}

The Black church has played a paramount role in the life of Black America throughout its history and especially in its struggle for freedom and upward mobility. Before emancipation, after emancipation, and in present times the Black Church has been a dynamic institution in socially intervening in order to achieve social reform for its community. This is especially true of the African Methodist Episcopal Church (AMEC) that has assisted the Black community in many ways. However, this thesis will focus on the ways that it has aided its community in mobilizing itself using education as a primary tool.

When the AMEC was founded in 1816, it understood that as a church it had not only a spiritual purpose but a social one as well. The denomination originated because of theological differences as a result of a social crisis. Though identical in its basic doctrine and order of worship, the AMEC differed from the Methodist Episcopal Church in terms of its practice. Blacks believed that racism and Christianity were incompatible; however, there were some Methodists that did not hold the same belief. According to David Childs, "It [the AMEC] was created in the racist climate of the late eighteenth and early nineteenth century". ${ }^{1}$ African Americans read and interpreted the bible as a text in which liberation and freedom were inspired. Due to adversity and hardships as a result of men's intolerance of their brothers based on the color of their skin, the denomination developed

\footnotetext{
${ }^{1}$ Childs, The Black Church and African American Education: The African Methodist Episcopal Church Educating for Liberation, 1816-1893, 6
} 
separately from the established Methodist churches. The AMEC was devoted to living like Jesus Christ. Christ did not discriminate nor did he oppress. The racial issues plaguing society tainted the manner in which the Methodist Episcopal Church practiced Christianity. Slavery, oppression, and the dehumanization of people of African descent are what caused Richard Allen, with support from representatives from other Black Methodist churches, to create the AMEC. His motive was inspired by what is now termed Liberation Theology. Allen was determined to provide his community with a religion that catered to its spiritual and secular needs.

The book of Exodus has been exceedingly meaningful to African Americans. The story narrates the suffering of Israelites caused by Egyptians. The Israelites had been slaves of the Egyptians, and their deliverance by God is a biblical event that resonates with many Blacks. The relationship between slavery and divine rescue often was heavily present in the theological perceptions of Black laity and was a prominent theme of Black preaching. According to Eric Lincoln and Lawrence Mamiya, "A major aspect of Black Christian belief is found in the symbolic importance to the word freedom". ${ }^{2}$ African Americans have always been able to identify with the concept and language of liberation or freedom. Biblical verses such as "now the Lord is that Spirit: and where the Spirit of the Lord is, there is liberty" or "stand fast therefore in the liberty wherewith Christ hath made us free, and be not entangled again with the yoke of bondage" consistently presents itself in Black theology ${ }^{3}$.

\footnotetext{
${ }^{2}$ Lincoln and Mamiya, The Black Church in the African American Experience, 4

${ }^{3}$ King James Bible II Corinthians 3:17 and Galatians 5:1, King James Bible
} 
The concept of liberation and freedom is not to be simply applied to the historical enslavement of Blacks, but also to the educational and subsequently economic bondage of Blacks associated with the aftermath of slavery. Before emancipation, Blacks believed in divine rescue as the only avenue to which they would be freed from bondage. However, Black Christianity's perception of emancipation has always been a spiritual and secular goal. Release from bondage was something that Blacks could bring about themselves. Richard Allen believed that education could act as "the weapon to develop the mind of the African to advance the welfare of his people". ${ }^{4}$ For Allen, education was conceptualized in a religious manner. It gave Blacks the necessary tools to read and interpret the Bible independently. Therefore, it gave Black religious leaders freedom to minister to the Black community, their community. This connects to the theme of selfdetermination and self-help. With each AMEC religious leader, education developed with the time and the various meanings of liberation. When Africans were first brought to the United States, they were originally from many different countries and were culturally diverse. Christianity became the uniting factor for most Africans. With each new generation, Africans used Christian hymns and the gospels to assist them in enduring and eventually combating the oppressive state of being enslaved.

When Allen first became a bishop, slavery was still widespread. For Allen, education was uniquely attached to Christianity. If he were to start the AMEC and expand its reach, each minister would need to know how to read to be effective ministers. Reading the Bible, was a form of liberation in itself. When Allen left the Methodist Church due to racial discrimination, it was to fight against subjugation. Founding the

\footnotetext{
${ }^{4}$ Alexander, Richard Allen: The First Exemplar of African American Education, 98
} 
AMEC in order to provide Blacks with a place to worship free from racial discrimination was a form of self- determination. Learning to read the Bible was a form of self-help, enabling Blacks to practice Christianity independently. All of these actions and decisions were necessary during Allen's time and education thought of in a religious context was fundamental to African Americans' ability to endure and then contest the racist climate of the early $19^{\text {th }}$ century. Allen's founding of the AMEC was the first account of the Black Church intervening socially on behalf of the Black community. The establishment of the AMEC was one of the first forms of autonomy that the Black community took for itself. When Daniel Payne was elected bishop in the late $19^{\text {th }}$ century, the significance attached to education and the meaning of liberation was changing rapidly. In 1963, Payne was elected bishop and in that same year slavery had been abolished. Education was becoming more attached to socioeconomic liberation because of its ability to elevate African Americans socioeconomic position in the American society. Gaining an education that was practical was just as important as acquiring an education for spiritual purposes. Education and its attachment to upward mobility would continue to be interconnected during Richard Robert Wright Jr.'s time as bishop and well into the $21^{\text {st }}$ century.

Christianity has always been the uniting factor for African Americans. It was the one religion that brought together the diverse cultures of Africans brought to the United States during the Atlantic Slave Trade. The slave trade brought various cultures, languages, and religions from Africa to America. This was intentional and was believed to prevent Africans from banding together in order to rebel. However, despite the cultural, linguistic, and religious differences, Africans identified with the message of 
Christianity. Christianity, with its concepts of liberation and neighborly love bonded Blacks together and provided them with a gospel that was able to help them better understand this foreign place where they were now to call their home. It's ability to unite persisted throughout the generations. For African Americans, the church was not simply an esoteric and spiritual institute. It was both a spiritual and secular institute. It was the place where African Americans learned to be God abiding Christians, but also where they learned Liberal Arts and Industrial education and how to effectively use the gained knowledge to gain socioeconomic freedom. Throughout history and in modern times, the AMEC uses Christianity as a tool to assist African Americans in dismantling the systems intended to oppress the Black community. In each century, the needs of the Black community have changed and each time it changed the AMEC was keen to providing the community with spiritual and social support. Black Christianity has always been an adherent to the Social Gospel, even before the term was coined and popularized.

Therefore, the AMEC's purpose was and is to liberate Blacks spiritually as well as socially and education is the tool that was and continues to be used in order to do so. This research examines the historical and contemporary AMEC's educational aspirations and how the AMEC's definition of education has evolved in each century to assist African Americans in combating their socioeconomic struggles. The focus of the study is from the late the late $18^{\text {th }}$ century to the $21^{\text {st }}$ century and evaluates how the AMEC has reformed itself as an institution to assist the Black community in mobilization. Initially, in the $19^{\text {th }}$ century a rudimentary education was the most urgent necessity for Blacks, which the AMEC provided. In contemporary times, African Americans are steadily progressing in their academic achievements, but their wealth and income is not, therefore, 
now the AMEC is focusing on economic education and providing the African American community with better economic opportunities such as housing and business ownership. From the beginning, Christianity has been adopted by Blacks to support socio-economic ailments; the AMEC remains devoted to the original purpose of Christianity for the Black community, which is to provide unity, guidance, and relief.

\section{Problem Statement}

Historically, the Black Church intervened socially in order to help its members combat the socio-economic struggles of their time. Financial and educational programs were created to support members of the Black Church. While these historical programs were useful to the Black community, it is important to analyze what the Black Church, in this case, the AMEC is doing in modern times to help Blacks' current socio-economic position in society. It cannot be denied that African Americans have made significant progress and one of the most noteworthy causes contributing to the progress of Blacks was their faith in God. Christian churches have played a paramount role in the social and economic successes of Black America. The question is whether or not Black churches can continue to be the instruments of empowerment that they traditionally have been. While African Americans have made progress, they are still severely struggling socially and economically. When considering the different economic statuses in America, a study by the Pew Research Center reports, "Blacks on average are at least twice as likely as Whites to be poor or to be unemployed". 5 The poverty gap has decreased since the mid

5 "Demographic Trends and Economic Well-being." Pew Research Center's Social \& Demographic Trends Project. July 25, 2016 
1970s when 30\% of African Americans were living below the poverty line, which was four times higher than Whites that were living in poverty. ${ }^{6}$ However, in regards to both races' median net worth, "White households are almost 13 times as wealthy as Black households - a gap that has grown wider since the Great Recession". ${ }^{7}$ Though statistics show that growing numbers of Blacks are completing high school and college, there is still a large disparity in education between Blacks and Whites. ${ }^{8}$ In her 2015 article, "U.S. Education: Still Separate and Unequal" Lindsey Cook stated, "By age 2, disparities already show between Black and White children. Fewer Black children demonstrate proficiency in development skills such as receptive vocabulary, expressive vocabulary, matching, early counting, color knowledge, and number and shapes.” The article also states,

Once formal schooling begins, inequalities continue. More than 140,000 students were [retained] in kindergarten in the 2011-2012 school year. Black students are more likely to be held back [retained], despite mounting research showing that holding back children doesn't benefit them socially or academically and makes them more likely to drop out later on. Retention rates for students hit a high in ninth grade, when 34 percent of students held back are Black. While 12 percent of Black students are held back in ninth grade, just 4 percent of white students are, according to the U.S. Department of Education's Civil Rights Data Collection. When all grade levels are combined, Black students are nearly three times more likely to be retained as their white peers. They're also more likely to drop out before earning a high school diploma. ${ }^{9}$

\footnotetext{
6 ibid

7 ibid, paragraph 22

${ }^{8}$ Bialik, 5 Facts about Blacks in the U.S., Pew Research Center. February 22, 2018.

${ }^{9}$ Cook, "U.S. Education: Still Separate and Unequal." U.S. News \&World Report, U.S. News \& World Report, 28 Jan. 2015
} 
This evidence proves that despite the historical presence of the AMEC concerning education, the Black predicament persists. If we can figure out how the historical AMEC assisted Blacks in making financial and education gains, then we might be able to answer a larger question: what can the contemporary AMEC do, if they are not already doing it, to diminish the disparity in education and economics between Blacks and Whites. This research is meaningful because it is important to highlight the interplay between the church and social reform movements. Since its beginnings the AMEC's mission has been to uplift the Black community, and it has been able to do so effectively, even if the institution has not yet completely reached its goal. Perhaps, other churches and institutions can look at the work of the AMEC in order to gain insight as to how to close the racial gap in other areas. Furthermore, there is limited research on the benefits of Black theology and its effects on the Black community. The majority of religious studies and theology is singularly White male oriented. It is now a new era, in which we must diversify academia and to look at all of the contributors.

\section{Research Questions}

- Is the contemporary AMEC as actively engaged in social reform as it once was historically?

- What is the interplay between the government and the church, and how does this interplay affect the church programs geared towards money and education?

- What are the practical measures of the church? 
- What is the relationship between money and education, and how does the church recognize the relationship and inform its community?

- Have the social programs offered by the AMEC changed? If so, how have they developed or evolved?

- Is the government financially assisting individuals so much that the church now has a more dominant focus on education and literacy as opposed to economics?

\section{Research Methodology}

The first part of the study, which focuses on the historical AMEC, uses both a comparative and historical approach. First, the thesis examines the historical role the church played in promoting education and the effects it had on its members. Historical information was gathered from publications of the AMEC from the 1800s, such as The AME Review, The Christian Recorder, The Journal of Christian Education, General Conference material, and Combined Minutes. The efforts of past AMEC leaders were then compared to the efforts of current programs offered by the AMEC. The same official AMEC publications, listed above, were used in order to illustrate the different initiatives and programs that the Church endorsed as a whole. Looking at the same official publications is useful because it acts as a sort of before and after of what the church did compared to what it is doing. By examining official AMEC documents and publications of AMEC leaders, the writer was able to cognize the goal of the entire church body; oppose to looking at only local churches, which would have limited the scope of the thesis. The purpose for using these methodologies is that they illuminate the type of discussions that AMEC leaders were having and highlights past, present and possibly 
future trends. Furthermore, it allows for a better understanding of the AMEC as a social institution; present solutions to contemporary problems found in the past; and underscore the key interactions between the Black Church and the Black community.

The study then used a historiography; it explained the relationships and interactions between historical individuals, events, ideas, and concepts. The first portion of the study ultimately laid a historical framework in support of the thesis.

\section{Research Objective}

The objective of the study is to compare the historical AMEC to its contemporary self. The study traces the evolution of the AMEC from the late $18^{\text {th }}$ century to the $21^{\text {st }}$ century and examines its tendency to socially intervene on behalf of its community. It analyzes the various initiatives of the church established to provide the members of the Black community with social advancement. In order to do this, it considers the various AMEC leaders and how they recognized the connection between the church and the secular world and education and economics. It analyzes the role of the Black Church as a social institution and the innovative educational programs created by it to provide Blacks with the tools that they need to help better their socio-economic position. It sought to assess the effectiveness of the Black Church as a social reformation institute and the manner in which it uses education to reform the Black community.

\section{Relevance of the Study}

As Doctor and Reverend Floyd Flake states, "The history of the founding, growth, and development of the African Methodist Episcopal Church within the crucible of the 
Protestant Church, the womb of the Methodist Church, and the matrix of the African American church, is one of the most phenomenal events in the annals of American history". ${ }^{10}$ This statement is illuminating in the sense that it understands and declares that Black history is a part of and not separable from American history. For a long time, white history has been taught as the sole history. Briefly mentioned, most times not, were the histories of non-white individuals. This study is relevant because it diversifies academia and seeks to reveal American history in entirety - including all of its participants and contributors. There is research that discusses the AMEC and its tendency to socially intervene on behalf of the African American community, but there isn't research that traces the evolution of the church from the late $18^{\text {th }}$ century to the $21^{\text {st }}$ highlighting the church's realization that there is a connection between education and socioeconomic stability and advancement. This research contributes to the scholarly discussions involving the AMEC because it makes a connection between educational and economic attainment in the past and in contemporary times; furthermore, it evaluates the various programs and initiatives that the church developed and promoted to bring about each.

The emergence of the AMEC in America in the $19^{\text {th }}$ century represents the beginning of the reformation of American Methodism. This study recognizes Richard Allen as the pioneer of Liberation Theology. According to Philip Berryman, "Liberation Theology represents a movement toward human emancipation, an interpretation of the Christian faith out of the suffering of struggle and hope of the poor; a critique of society

\footnotetext{
${ }^{10}$ Flake and Allen, The Religious, Social, Political and Economic Development Ministry of Richard Allen: A Model for the 21st Century African American Church, 1
} 
and the idea logos sustaining it". ${ }^{11}$ Though the term Liberation Theology was not yet coined, what Allen began was essentially Liberation Theology through and through. The rise of the African Methodist Episcopal Church was not due solely to a racial climate, but on the contrary, due to the theological underpinnings attached to the discriminatory practices of the denomination. Allen viewed Christianity as a religion of salvation and liberation; salvation clearly demonstrated by Jesus Christ throughout the bible. The various scriptures revealed the unchristian practices of the Methodist Church. In an attempt to detach itself from unchristian practices and to preach the true gospel of salvation and liberation, Allen founded the AMEC. This study is necessary because it presents the creation of the AMEC as a decision by African Americans to practice and subscribe to the true Christianity oppose to the one offered to them by their oppressors. It presents Black Christians as active participants in their faith opposed to blank impressionable canvases. It presents self-determination, self-help, and self-advocacy. Though extensive research has been conducted on the AMEC, there currently isn't any research that traces the evolution of the African Methodist Episcopal Church and its tendency to socially intervene on behalf of its community's socio-economic position from the late $18^{\text {th }}$ century to the $21^{\text {st }}$ century. The relevance of this study lies in its ability to demonstrate how the AMEC has elevated its community through education and economic initiatives.

${ }^{11}$ Berryman, Liberation Theology, 6 


\section{THE ORIGIN AND DEVELOPMENT OF THE A.M.E.C AND ITS EDUCATIONAL INITIATIVES}

\section{Methodist Episcopal Churches}

The irony of slavery in America is due to the fact that people in search of freedom founded America. James Brawley asserts, "The upheaval of the Western world started a sensitive reaction to the intolerance of the Established Church. Thus, the hope of the New World in America was for a new civilization and a haven of escape from oppression". ${ }^{12}$ However, once the English arrived, they began to develop the New World by way of the very thing that they were trying to escape back at home, oppression. The development of America occurred according to two different ideologies. The North developed based on a theocratic government. A theocracy is a form of government in which a religious institution is the source from which all authority derives. "The high level of education and dominance of the clergy enabled the settlers in New England to build a high moral and spiritual foundation... the ideals of the Puritans and Quakers furnished the dynamics for church, school, and government". ${ }^{13}$ However, the South was less concerned with religion and more with money. "For the South the motivation was more in the field of commerce and economics... economic exploration and exploitation were the dominating

\footnotetext{
${ }^{12}$ Brawley, Two Centuries of Methodist Concern: Bondage, Freedom, and Education of Black People, 19-20

13 ibid, 19
} 
motives". ${ }^{14}$ Slavery would become one means of economic exploration and exploitation, one that most Methodists opposed greatly.

During the colonial period, there was no organized Methodist Church. However, once the organization begun to develop it did so in an era of social revolution. Early Methodists protested slavery and advocated for social reform. The philosophy of natural rights stirred certain politicians and the Fathers of the Methodist Episcopal Church to detest slavery. From the middle of the $18^{\text {th }}$ century to the end of the American Revolution war, many individuals began to openly detest slavery. This protest was occurring in the American colonies and England. Due to such strong revolutionary orientation in both America and England, individuals such as Francis Asbury, Thomas Coke, and John Wesley, amongst others, who would eventually become the Fathers of the Methodist Episcopal Church, would set out to openly protest against slavery. According to James Brawley, “ They [Methodist leaders] protested slavery and gave impetus to social reform in the newly organized Methodist Episcopal Church..."15 Methodist beliefs strengthened once the Declaration of Independence was written. While there were many individuals, the overwhelming majority, that did not practice the concept of "self-evident truths that all men are created equal and that all are endowed with certain unalienable rights", as mentioned in the Declaration of Independence, the humane spirit of early American Methodism, before the actual divide of the church between the north and south, was

\footnotetext{
14 ibid

15 ibid, 19
} 
completely congruent with the principles set forth in the document. This is shown in the following declaration of the Methodist Episcopal Church:

We view as contrary to the golden law of God, on which hang all the laws and the prophets, and other unalienable rights of mankind, as well as every principle of the revolution, to hold in the deepest abasement... so many souls that are capable of the image of God. We, therefore, think it our most bounden duty to take immediately some effectual method to extirpate this abomination from among us. ${ }^{16}$

In November 1784, Thomas Coke and Francis Asbury made plans to gather all Methodist preachers together for a Christmas Conference at Lovely Lane United Methodist Church in Baltimore, Maryland. According to historian John Strawbridge, the historian of Lovely Lane United Methodist Church, the Methodist preachers met over a course of ten days in order to form a new denomination. Gathered were approximately eighty-six preachers; together they established The Book of Discipline. ${ }^{17}$ The quote above, originating from this first conference at Lovely Lane United Methodist Church, shows the Methodists position regarding slavery. From its inception, the Methodists, even before it officially became a denomination, were concerned with the problem inherent in slavery. In the conference minutes of 1780, in Baltimore, Maryland, the Methodists position regarding slavery is made clearer:

\footnotetext{
${ }^{16}$ Cameron, op. cit., p. 99. Quoted in Brawley p. 24

${ }^{17}$ United Methodist Communications. "Methodist History: The Christmas Conference." The United Methodist Church. December 12, 2018. Accessed March 05, 2019. http://www.umc.org/who-we-are/methodist-history-the-christmas-conference.
} 
Does the conference acknowledge that slavery is contrary to the laws of God, man, and nature, and hurtful to society; [it's] contrary to the dictates of conscience and pure religion, and doing that which we would not that others should do to us or ours? Do we pass our disapprobation on all our friends who keep slaves and advise their freedom? Yes. ${ }^{18}$

The Methodist Episcopal Church, not yet officially divided between their principles in regards to slavery, which occurred in 1845, would experience extremely differing views on the topic of slavery; these beliefs of slavery's wrongness or rightness, would intensify due to the conference of 1780. Though still joined, the Methodist Episcopal Church, primarily the northern ones, would organize abolition movements. The first abolition society was founded in 1774. What's worth mentioning is that it was founded in Pennsylvania. Pennsylvania is where the first African Methodist Episcopal Church was founded, Mother Bethel A.M.E. Church. After the first abolition society was founded, many others came into existence.

Many Blacks migrated to Methodism because of its stance on slavery. Though Methodists are regarded as being highly influenced by Quakers and Puritans and being in favor of equality for all, not all Methodists believed this. There were some Methodists that supported slavery, especially those residing in the south. Understandably so, considering that the south planters yielded a sort of power, prevailing in both political and social influence. Planters had a sort of aristocracy, which makes it evident that the equality spoken of in the Declaration of Independence was not accepted nor was it well received in this section of the United States. Aristocracy and the slavery that the majority

\footnotetext{
${ }^{18}$ Minutes, Methodist Annual Conference, 1780, p.12 quoted in Brawley p. 28-29.
} 
of the planters required in order to maintain their social classes were the exact antithesis of equality. According to Brawley:

There were at least two groups of Methodists who were opposed to the Methodist Anti-Slavery society and the abolition movement in general. One of the groups was giving support to the Colonization Society and thought that this was the best method of dealing with the question of slavery. The second group opposed to the Methodist Anti-slavery was the group that favored slavery and wanted to maintain the institution without interference. The second opposition group can be understood when it is recalled that the center of gravity of Methodism as pointed out above was in the South. ${ }^{19}$

This quote highlights the different views within the one denomination. There were three views: slavery was wrong and thus should be abolished; the Colonization Society, also known as the Back-to-Africa Movement, believed that the best solution to the slavery problem was to encourage individuals of African descent to return to the homelands of their ancestors; and lastly, slavery was not evil and therefore should be maintained. While many Methodists prided themselves on having egalitarian ideologies, there were many that did not. In fact, the Great Methodist Schism of 1844 can speak to this very fact. Because of sharp differences in views regarding the enslavement of Blacks, the church separated in 1844 into two groups: the Northern group retained the name Methodist Episcopal Church, while the southern group took the name, the Methodist Episcopal Church, South. The membership of the South's Methodist Episcopal Church was segregated, and religious instruction given to slaves was limited and focused upon justifying the institution of slavery. It can be argued that not all of the churches were on one side of the schism. Based on the fact that the officials at St. George's Methodist

\footnotetext{
${ }^{19}$ Brawley, James, Two Centuries of Methodist Concern: Bondage, Freedom, and Education of Black People, 34-35.
} 
Episcopal Church, located in Pennsylvania and considered a northern state, forced its African American congregants from their knees while in prayer to relocate because they were in what was considered the white area, proves that there were churches that did not necessarily believe it proper to enslave Blacks but also did not recognize them as citizens or equal to the majority population. This is one reason why the AMEC originated. The discrepancies between Methodists and their religious practices opposed that of liberation theology. In an interview with Terry Gross, conducted by the National Public Radio (NPR), the official founder of Black Liberation Theology, James Cone, explains that at the center of the Black Liberation Theology there is an effort on behalf of Blacks "to teach people how to be both unapologetically Black and Christian at the same time". ${ }^{20}$ Blacks desired to create a religious institution that was not segregated on their views of the humanity of Blacks but one that holistically understood that not only were Blacks humans, but they were equally and just as much human as their white counterparts. The discrimination and oppression within certain Methodist churches prompted Blacks to establish their very own church and theology, one that they believed was aligned with the true gospel message of liberation. This was shown when the African Methodists of St. Georges left in unison, due to unfair treatment because of their race. Richard Allen reflects on this moment in his book The Life Experience and Gospel Labors of the Rt. Rev. Richard Allen:

${ }^{20}$ Hagerty, Barbara Bradley, Black Liberation Theology, in Its Founder's Words, 2008. https://www.npr.org/templates/story/story.php?storyId=89236116. 
He came, and went to William White to pull him up. By this time prayer was over, and we all went out of the church in a body, and they were no more plagued with us in the church. This raised a great excitement and inquiry among the citizens, in so much that I believe they were ashamed of their conduct. But my dear Lord was with us, and we were filled with fresh vigor to get a house erected to worship God in. ${ }^{21}$

The unjust treatment of the African Methodists led to the dramatic withdrawal of the African Methodists, subsequently leading to the creation of the AMEC. In his book, History of the African Methodist Episcopal Church, Daniel Payne discusses the "unkind treatment of their white brethren, who considered them [Blacks] a nuisance in the house of worship" and that because of this treatment there was a meeting "to erect a house of worship wherein they could worship God under their own "vine and fig-tree". ${ }^{22}$ Finding a house of worship where they did not have to endure constant unjust treatment because of the pigmentation of their skin was very important for the Black Methodists. "Under their vine and fig tree", quoted three times in the Bible, describes the Black Methodists desire to live without fear, to live in peace and prosperity; because the lord has promised it.

Establishing an independent Black Church during this time period was difficult and took perseverance to sustain. After leaving the Methodist Episcopal Church, Richard Allen proposed that an African Methodist meetinghouse be erected at his own expense. The preachers of the Methodist Episcopal Church greatly opposed this and insisted that the house should not be made independent of the Methodist Episcopal Church. ${ }^{23}$ When

\footnotetext{
${ }^{21}$ Allen, Richard. The Life Experience and Gospel Labors of the Rt. Rev. Richard Allen ...Nashville: Abingdon Press, 1983, 14.

${ }^{22}$ Payne, Daniel Alexander. History of the African Methodist Episcopal Church. North Stratford, NH: Ayer Pub., 2000, 4

${ }^{23}$ ibid, 5
} 
the building was finished; Bishop Asbury consecrated it. The house was named Bethel. Shortly after Allen had established Bethel, a resident Elder proposed that the church should be incorporated so that they might receive donations or legacy. Once the Black Methodists agreed to this, the Elder then proposed to create the document. After having signed the document, Allen realized that the deed was written in such a way that relieved the Black Methodists of all of the liberties they hoped to enjoy. For example, often the keys to the church were demanded and permission was required to have meetings. Consequently, the congregation had to sign a petition to the Legislature of Pennsylvania for a supplement to their deed and it was granted. This helped to ease the troubled relationship between the Methodists and the Black Methodists, but it did not end it. Allen was adamant about receiving the liberty he desired and had worked so hard for. According to Daniel Payne:

\begin{abstract}
Allen took the deed of the church to proper parties, who told him that according to the letter and spirit of the deed, Mr. R (Methodist Preacher) could lock up the church against him, and that he could prevent this only by having a supplement to the deed. This was drawn up immediately, and acknowledged by the Judges of the Supreme Court. The authorities at Lancaster, the seat of government, where it was sent, then confirmed it. ${ }^{24}$
\end{abstract}

After Allen had secured Bethel's Liberty and took back the Black Methodists right to worship and meet whenever they so desired, the Methodist Episcopal Church declared that Allen and his adherents were no longer members of the Methodist Episcopal Church. The result of the separation from the Methodists Episcopal Church

${ }^{24}$ ibid, 8 
was beneficial for the Black Methodists. The African Americans had to work collaboratively to sustain the building. Only by working in unison were they able to supply the pulpits with preachers, deacons, and elders. Prior to the separation, the Black Methodists relied on the Methodists to supply the pulpit and offer the instruction. Now, the Black Methodists had an opportunity to exercise self-help and independence. After separating from the Methodist Episcopal Church in 1787, the Black Methodists begin to organize the AMEC. In the early $19^{\text {th }}$ century, they started electing bishops, discussing ways to better the Church's weak financial condition, and holding conferences to admit local preachers into seats in the Annual Conference.

In the $19^{\text {th }}$ century, the AMEC began to flourish. African Methodism began to rise in the city of New York. In 1820, New York and Brooklyn Churches were incorporated in the AMEC. ${ }^{25}$ In 1836, the AMEC's membership had increased and so did the salaries of its religious leaders. Two years later, on April $22^{\text {nd }}$, AMEC bishops met to discuss the importance of education for the adults, but most especially for the rising generation of the time. ${ }^{26}$ And in the 1840 's, the number of Sunday schools increased significantly. In this same time period, the AMEC's religious leaders assigned a committee to draft a document that would speak to their interest in education. On October $24^{\text {th }}, 1845$, the Preamble and Constitution was written and discussed the AMEC's educational aspirations. While the AMEC was increasing its membership, salaries, and exploring their education interests, the Methodist Episcopal Church was quarreling over anti-

25 ibid, 31-35

${ }^{26}$ Payne, Daniel Alexander. History of the African Methodist Episcopal Church. North Stratford, NH: Ayer Pub., 2000, 118 
slavery sentiments. The denomination experienced thirty years of intense struggle over of slavery. During this time, some Methodist Churches established abolitionist movements. Some churches opposed the establishment more than others. Eventually, the intense sentiments felt regarding slavery reached a dramatic climax when the Methodists Church split due to differing racial views in 1844.

\section{The Methodist Episcopal Church and Social Intervention}

The Methodist Episcopal Church was involved in a number of ways prior to the establishment of the Freedmen's Bureau. For example, before the ending of the war, several church denominations were working together to assist the newly freed Blacks. According to James Brawley, "The Methodist Episcopal Church became a part of this movement by various denominations to minister to Freedmen in many different ways". ${ }^{27}$

According to an annual report by the Methodist Episcopal Church:

The General Conference of 1864 took cognizance of the humane work on behalf of the Freedmen of the United States as prosecuted by the leading Freedmen's aid commissions - undenominational societies, organized to unite in a common work the friends of the Freedmen throughout the country, without reference to their religious opinions... the Commissions were, therefore, approved by the General Conference as engaged in a work of benevolence of special interest, and commended to our people everywhere so worthy of their sympathy and support. ${ }^{28}$

In addition to these commissions, several more developed in the East and the West, consequently leading to the development of a National Commission, focused on

${ }^{27}$ Brawley, James, Two Centuries of Methodist Concern: Bondage, Freedom, and Education of Black People, 34-35.

${ }^{28}$ Annual Report of the Freedmen's Aid Society, 1868, p.3 
aiding the Freedmen. However, after several years, the large number of denominations, such as the Congregationalists, Baptists, Presbyterians, which were originally devoted to the non-denominational commissions, began to withdraw from the National Commission, and develop their very own societies in order to help African Americans. This caused the Methodist Episcopal Church to believe it was time for her to do the same. Therefore, the church established the Freedmen's Aid Society. The society's purpose was to relieve and educate Freedmen. Methodists proposed the question: Shall we organize a Methodist Freedmen's Aid Society? To this question they provided eight answers. Of these, there are three directly related to education: the creation of Methodists schools to be taught by Methodist teachers; increasing the effectiveness of Methodists Sunday Schools, while simultaneously working to include African Americans; the Society would allow Methodists to directly educate the Freedmen. The Methodists saw many benefits of founding their own missionary work in regards to African Americans. This is described in their statement:

The schools organized would be supplied with Methodist teachers, and might be under the local supervision of our Missionaries, thereby securing to them a religious character congenial to the habits and feelings of the colored people; it would further strengthen our missionary work by furnishing Sunday School teachers, and increase the efficiency of the Sunday Schools by making them a part of the Church movement; a Methodist Freedmen's Aid Society would give our Church a more direct, and hence a greater, interest in the education of the Freedmen, and consequently increase the zeal of the mission-work in their behalf. $^{29}$

${ }^{29}$ Report of the Freedmen's Aid Society, 1866-1875, p. 5-9 
The answers provided by the Methodists are telling because they express the innate desire of the members to not only be directly involved in zealous missionary work but also to do so on behalf of the newly freed African Americans. This shows that the Methodists had an understanding of the difficulty that Blacks experienced by being released from bondage and forced to make a living for themselves on their own merit without the tools to do so. It also highlights the emphasis placed on education as a means to provide Blacks with stability. The statement expresses an understanding that education was a prerequisite for religious commitment, citizenship, economic freedom, and equality.

After the Civil War and the Emancipation of slaves, the Methodist Episcopal Church was directly involved in the affairs of the Freedmen. In 1864, the church suggested "the establishment of the National Freedmen's Bureau which the congress approved in $1865 "{ }^{30}$ The church in the north was active in assisting newly freed African Americans navigate their new position in the American society. From 1864-1865, the Methodist Church was directly involved in the affairs of African Americans in the south. Several missionaries were sent to Blacks in the south, a large sum of money was allocated to support the establishment of churches, Sunday schools, and day schools. Most importantly, after ensuring that as an institute it had did all that it could have to assist the new American citizens, the Methodist Church asked the government for support. There were several publications and various conferences urging the government to support African Americans by establishing a Freedman's Bureau. Among the many resolutions passed by the General Conference of 1864 , there is one that is especially

${ }^{30}$ Allen, Richard. The Life Experience and Gospel Labors of the Rt. Rev. Richard Allen ...Nashville: Abingdon Press, 1983, p. 56. 
noteworthy and it states, "that the best interests of the Freedmen, and of the country demand legislation that shall foster and protect this people". ${ }^{31}$ The address goes on to urge the congress to establish a bureau of African American affairs. W.E.B. Du Bois states, "The Freedmen's Bureau was the most extraordinary and far-reaching institution of social uplift that America has ever attempted. It had to do not simply with emancipated slaves and poor whites, but also with the property of Southern planters. It was a government guardianship for the relief and guidance of white and black labor from a feudal agrarianism to modern farming and industry". ${ }^{32}$ The role of the Methodist Episcopal Church in the creation of the Freedmen's Bureau shows their continued advocacy to improve the situation of Blacks after the Emancipation Proclamation.

Education was vital for Blacks because it provided them with the tools necessary to support themselves as new citizens of America. It liberated their minds in a way that the Civil War and Emancipation could not. The widespread belief that Blacks should forever be a hewer of wood and a drawer of water could be debunked by the opportunities revealed by education. This is not a theory held solely by Blacks and liberal church members but also by oppressive members of American society; this supports the reason why they so fervently opposed the educating of Blacks. The majority of Blacks were illiterate. This is understandably so since little instruction was provided to them during slavery and when Blacks attempted to self educate or educate one another there were severe, and at other times, fatal consequences. Brawley states, "It was thought that

${ }^{31}$ General Conference Journal, 1864, p. 130.

${ }^{32}$ Du Bois, Black Reconstruction in America, 219 
to keep the Negro illiterate would help to keep him in his place". ${ }^{33}$ This was the general belief of southerners. But, many Methodist Christians believed otherwise. The church was directly involved in the educating of Blacks when the government was not. D.W. Clark, secretary of the Board in the Freedmen's Aid Society made an address to the pastors and members of the Methodist Episcopal Church declaring, "The time may come when the states in the south will make some provision for the education of the colored children now growing up in utter ignorance in their midst. But thus far they have made none, nor perhaps can it soon be expected of them. Christian philanthropy must supply this lack". ${ }^{34}$ Thus, the work of liberating the minds of Blacks began.

The first thing that the Society did was to establish schools. The establishment of schools occurred swiftly and over a large geographical area. Initially the church provided the South with elementary and secondary schools in order to provide the basic foundation. However, there was a great emphasis placed on productive labor. Therefore, according to James Brawley, there was a focus "upon industrial education. It was thought that the best way for the Negro to gain independence was through productive labor and the development of economic strength". ${ }^{35}$ The education provided was directly linked to the immediate success of the Black population to attain a source of revenue. The church goal was not simply to educate Blacks but to educate them in such a way that the entire

33 Brawley, Two Centuries of Methodist Concern: Bondage, Freedom, and Education of Black People, 47

${ }^{34}$ Freedmen's Aid Society Report, 1866, 1

${ }^{35}$ Brawley, Two Centuries of Methodist Concern: Bondage, Freedom, and Education of Black People, 83 
racial group would be able to sustain themselves economically. Therefore, there was a direct connection between education and economic stability. The basic concern was the development of the race. The Society's ability to develop schools proved to be successful. In the beginning of its operation the society opened many schools meant to educate Blacks. Based on a report by the Freedmen's Aid society in 1868, “within the first seventeen months of the operation of the Freedmen's Aid Society in the south fiftynine schools were established". ${ }^{36}$ In addition to the elementary schools, the Freedmen's Aid Society also established colleges, academies, and theological schools.

In the 1870 's, the Methodist Episcopal Church and the Society wanted to become less involved in elementary and secondary schooling and more involved in higher education. The church was no longer willing to provide the south with rudimentary schools. The Sixth Annual Report of the Freedmen's Aid Society, 1873, spoke about channeling more of it efforts towards theological education, teacher training, and collegiate work. Moreover, the church realized that the longer it provided the south with elementary schools, the longer it would take the government to do so. According to Brawley, “...there were few, if any, public schools for Negro children. The public school system in the South was slow in its development after 1865 for several reasons". ${ }^{37}$ A lack of commitment to free public schools for all children and economic instability due to the economic reversal as a result of the Civil War, are two of the main reasons why the south

\footnotetext{
${ }^{36}$ Report, Freedmen's Aid Society, 1868, 10

${ }^{37}$ Brawley, Two Centuries of Methodist Concern: Bondage, Freedom, and Education of Black People, 103
} 
did not provide elementary education. ${ }^{38}$ The Freedmen's Aid Society had thought that the states would eventually provide education to all, especially after the Civil War, but this did not occur. Consequently, it began to withdraw from elementary and secondary schools and swiftly began to establish colleges, academies, preparatory schools, and theological schools; the Society believed that it was not its responsibility to provide elementary education indefinitely. The purpose of the Society was to propel the new citizens of America; providing them with a basic level education only stunted their potential and put them in a perpetually stagnant position. This is why the Society endeavored to create higher education institutions, and it did just that. Within its first fifty years of history, the Freedmen's Aid Society established twelve colleges, twenty academies, and two theological schools. It is evident that the Methodist Episcopal Church, the parent church from which the AMEC originated was completely consumed with bettering the lives of Blacks in America, but so was the AMEC. On March 1863, the AMEC agreed with the original trustees of Wilberforce University, the Methodist Episcopal Church, to purchase the property for the AMEC. Due to the denial of African Americans into colleges and other institutions of higher education, the AMEC purchased Wilberforce in order to provide Blacks an institute where they could further their education. There were less than a handful of schools of higher education that allowed Blacks entrance, one of which being Oberlin College, the first college to allow Blacks admission. ${ }^{39}$ Therefore, bishops of AMEC applied for a new charter for Wilberforce

\footnotetext{
38 ibid

${ }^{39}$ Payne, Daniel Alexander. History of the African Methodist Episcopal Church. North Stratford, NH: Ayer Pub, 2000, p.429
} 
University in the name of the AMEC; under this charter there was a reorganization of the board of trustees, and Professor John G. Mitchell reopened the school on July 3rd, $1863 .{ }^{40}$ When the college opened, there were only six students present. However, it only took ten months after which for that number to increase. Originally, students were placed with the task of studying elementary English, but as the student population grew, Wilberforce University began to hire more professors and offer more courses. Some of these courses were Greek, Latin, and Mathematics. After the burning of the college in 1865 , and thus the rebuilding of it the following year, the college was energized and zealous and opened even more departments than what it originally offered. According to Payne, "the Theological and Classical Departments were opened in the autumn of 1866, the Scientific in 1867, and the Normal in $1872 .{ }^{41}$ What becomes clear in this period is that African Americans were not going to school anymore simply to learn to read the Bible but to gain an education that would give them knowledge of the world and provide them with a sort of intellect that would enable them.

Simultaneously, the Methodist Episcopal Church was endeavoring to provide African Americans with an education that they believed would immediately yield economic revenue. Brawley was correct when he asserted, "Preparation for the improvement of the economic life was an essential part of the philosophy of the leaders of the Freedmen's Aid Society. Consequently, provisions were made for educational training that would lead to proficiency in skilled labor. Industrial education and manual

\footnotetext{
${ }^{40}$ ibid

${ }^{41}$ ibid, 430
} 
training assumed an important position in the system of education established". ${ }^{42}$ Industrial education is an approach to learning from an industry perspective. Skilled labor and industrial education can be conceptualized through the lenses of Booker T. Washington. In October 1903, Booker T. Washington wrote about industrial education for African Americans and though it was written after the Methodist Episcopal Church established their general educational objectives, it precisely defines the motives of education in the late 1800s. For Washington, industrial education for Blacks was focused on the industry of slavery. When slaved, Blacks were required to work with their hands, oppose to with their brains. For example, the manufacturing of buildings, clothes, and shoes were all skills learned from the industry of slavery. In his book Industrial Education for the Negro, Washington states, "In a certain way every slave plantation in the South was an industrial school. On these plantations young colored men and women were constantly being trained as not only as farmers but as carpenters, blacksmiths, wheelwrights, brick masons, engineers, cooks, laundresses, sewing women, and housekeepers". ${ }^{43}$ To many Blacks, both normal civilians as well as philosophers, it seemed counterintuitive to be freed from slavery simply to return to the work of it. Going back to work land owned by former plantation owners was viewed as a negative, even if Blacks were now being paid to do it. However, others felt that manual labor was something that many Blacks were skilled in. Again, Washington, a proponent of industrial education, states:

${ }^{42}$ Brawley, Two Centuries of Methodist Concern: Bondage, Freedom, and Education of Black People, 99

${ }^{43}$ Washington, Booker T. Industrial Education for the Negro. 1903, p.1 
I do not mean in any way to apologize for the curse of slavery, which as a curse to both races, but in what I say about industrial training in slavery I am simply stating facts... The industries that gave the South its power, prominence and wealth prior to the Civil War were mainly the raising of cotton, sugar cane, rice and tobacco. Before the way could be prepared for the proper growing and marketing of these crops forests had to be cleared, houses to be built, public roads and railroads constructed. In all these works the Negro did most of the heavy work. In the planting, cultivating and marketing of the crops not only was the Negro the chief dependence, but also in the manufacture of tobacco he became a skilled and proficient workman, and in this, up to the present time, in the South, holds the lead in the large tobacco manufactories. ${ }^{44}$

There were many theorists that believed that the industrial education provided by slavery could be beneficial in correcting the socio-economic dilemma of Blacks. The skills already acquired in slavery were skills that could be further developed with schooling and perfected. It was a field of work that would immediately yield profit. Industrial education had potential to be very helpful; learning how to use machinery to aid in farming and factory work yielded a source of income. An industrial education was also useful for Northerners since the North was rapidly industrializing. Manual labor included principles of effective farming. For example, rotating of crops and amending the soil were useful skills, especially in the South where the economy was based largely on agriculture. Although generating revenue in order to promote the socio-economic well being of the Black community was of utmost importance, so was the development of Blacks cultural life. Therefore, according to Brawley, "provisions for the development of the cultural life through education were in the areas of liberal arts, classical education,

${ }^{44}$ Washington, Booker T. Industrial Education for the Negro. 1903, p.2 
philosophy, and the fine arts". ${ }^{45}$ In short, Blacks were receiving a classical education. This type of education was also beneficial because it taught skills that were transferrable. It was only a matter of time before the students were also studying languages such as Latin and Greek and focusing on higher mathematics. As Black students progressively became more acquainted with the education being provided, the society began to prepare African Americans for professional work. There were also courses offered to prepare them for theology, teaching, medicine, dentistry, and law. ${ }^{46}$ The Methodist Episcopal Church and the Freedmen's Aid Society objectives are clear: to provide Blacks with a status of equality as both a man and citizen. This objective was made possible with education. The gradual implementation of education and the diversifying of it illustrate the motives of the Freedmen's Aid Society. The Society was diligently acting to promote a holistic livelihood for Blacks.

As early as the late eighteenth century the Methodist Episcopal Church had been instrumental in facilitating an environment for African American literacy and education". 47

In the nineteenth century, education for Blacks had to be provided by the church or religious philanthropists because the government was not providing public education in the South, which is where the majority of African Americans resided. As previously

${ }^{45}$ Brawley, Two Centuries of Methodist Concern: Bondage, Freedom, and Education of Black People, 99

46 ibid

${ }^{47}$ Childs, "The Black Church and African American Education: The African Methodist Episcopal Church Educating for Liberation, 1816-1893, 15 
stated, the South did not believe in education for all; moreover, it was suffering from an economic reversal because of the Civil War. As a result, colleges were predominately founded and operated by religious institutes. Brawley declares, "During the first 50 years of the existence of the colleges for Negroes, they were strictly under the auspices of the church". ${ }^{48}$ And it took twenty years of the $20^{\text {th }}$ century before it came to fruition. During this period the church played a dynamic role in providing Blacks with an education. The first college created for Blacks was Cheyney University of Pennsylvania, founded on February 25, 1837, by Richard Humphrey, a Quaker. Cheyney University was aligned with many of the philosophies of Booker T. Washington. Originally born on a plantation in the West Indies, Humphrey arrived in Philadelphia in 1764. Having seen the Black predicament in the United States, he provided one-tenth of his estate to the creation of a trade school that would teach young African American boys and girls the skills needed to be more competitive in the job market. His school taught subjects such as reading, writing, and math, in addition to mechanics and agriculture. Cheyney University is considered a Historically Black College (HBCU). HBCUs are institutions of higher education established in the United States prior to 1964 with the intention of serving the Black community. After the establishment of the first HBCU, Cheyney, 106 HBCUs were founded afterward. Out of this number, fifty percent of the institutions were religiously affiliated, with fifty-four out of 106 associated with a religious institute. Twenty-four of the fifty-four religiously affiliated HBCUs are considered members of the

48 ibid, 110-111 
Methodist Church family, including the AMEC. David Childs notes "the Methodist Episcopal Church has long played a prominent role in African American education". ${ }^{49}$ In many ways the AMEC was similar to the Methodist Church. The religious doctrines and ideals of each institution were very similar. Moreover, the AMEC replicated the educational practices and organization structures used by the Methodist Church. The AMEC was able to learn from its mother church so that it may create and facilitate its very own institutes. For example, the AMEC created its very own educational institutions. It created schools, colleges, and Sunday schools. According to Childs, the AMEC established educational institutions of their own including: colleges, normal schools (teacher colleges), Methodist class meetings, and Sunday schools. A year after the Civil War in 1866 the Church owned and operated 11 colleges and normal schools with more than 2,000 students. The church operated Sunday schools that focused primarily on biblical lectures and that by the end of 1885 , were serving some 2000,000 students. ${ }^{50}$ The numbers provided alludes to one major theme. It demonstrates the AMECs' ability to learn and recreate in order to promote concepts of self-help. Receiving support and guidance from others is helpful, but not sustainable. African Americans needed to liberate themselves through education and devotion to the Black cause. It also proves that the AMEC was directly involved in the educational achievements of African Americans. Members of the AMEC knew that they would receive both spiritual and worldly guidance from the leaders of their churches.

\footnotetext{
49 ibid

${ }^{50}$ Ibid, 17
} 


\section{The Black Church and Education}

The very creation of the Black Church was due to the need for Blacks to be simultaneously Black and Children of God. Often in predominately White churches, Blacks were treated as subordinate entities that were considered subhuman. Therefore, Blacks sought to create an institution that was both religious and social in scope. The institute's purpose was to fulfill the spiritual and temporal needs of the Black community. It was meant to offer Blacks a place to worship away from discrimination and biases, allow Blacks to worship in a way that was culturally appropriate for them, and offer solutions to external problems. This latter point is the focus Andrew Billinglsey's Mighty Like a River: The Black Church and Social Reform, which "provides the reader with a synoptic view of the travail and triumph of the Black Church as a social institution from antebellum times to the present". ${ }^{51}$ This work is important because it offers insight into what Black Churches were doing in the name of the Black community.

African Americans that attended church often attended White churches and though they were happy to finally be allowed in a church, the church was clearly not theirs. In these churches, Blacks were forced to be hyper aware of their race, which at the time was considered inferior. This was demonstrated by the relegation of Blacks to areas where whites were not; the silencing of their voice and presence; and also by denying African Americans the right to obtain any real leadership role, or any role at all, in the operation of the church. Worshiping in this environment seemed counterintuitive; though

${ }^{51}$ Billingsley, 1999, xix 
often not preached, there were times when gospels were taught that expressed ideals of liberation and accounts of Jesus interacting with the oppressed. Even on the simplest level, the gospel expressed love. In the introduction of Billingsley's book, Eric Lincoln asserts that when African Americans were finally allowed into the churches that the church demonstrably was not for them, "a communication that spoke pointedly and consistently through the sermons, the prayers, the spiritual suppression, and the absence of fellowship". ${ }^{52}$ The biblical tales defining the role of the master and slave were frequently expounded. This and the numerous sermons focused on Genesis 9, and the damnation of Blacks due to Ham's curse seemed to be a theme that African Americans were forced to hear and believe. It made evident the second-class citizenship or the otherness of Blacks. The white churches promoted African American oppression and the God of the white church had seemingly cursed Blacks and given them "travail and debasement in perpetuity. ${ }^{, 53}$ In cases where there were white churches that did not support slavery, there remained biases due to racial differences and beliefs of inequality. This is one reason why Billingsley states that the creation of the Black Church was meant to benefit the Black community and therefore evolved from its historical beginnings to modern times to help its community. During the Antebellum, and even more so afterwards, the Black Church was engaged in community service. Education, business, and economic developments were amongst the many church's many initiatives.

\footnotetext{
52 Billingsley, 1999, xxi

53 Billingsley, 1999, ibid
} 
History proves that Blacks have always held education in high esteem. When they were not granted opportunities to receive an education they taught themselves. Billingsley examines Atlanta and looks at the Blacks there and their strong participation in education. Ulysses S. Houston is but one example. Taught to read and write while working in a Marine Hospital, Houston later would use these acquired skills to become a prominent pastor at the Third African Baptist Church and a prominent member of the state legislature in $1868 .{ }^{54}$ In 1868 , Houston was one of the Original 33 African American legislators, members of the Georgia General Assembly, elected to office, during the Reconstruction Era. It is in this position that he hoped to diminish the Black quandary; however, he was unable to do this due to the conspiring against the Original 33 , subsequently leading to the Originals' expulsion or forced resignation. Prior to 1868 , twenty Freedmen, including Houston, met with the Union General William Tecumseh Sherman in 1865. Sherman was not an abolitionist before the war, and similar to many other individuals of his time, he did not believe in equality of the races. There were times that he sympathized with Southern whites' ideals. Nonetheless, he still believed that the Black race should not fall victim to some aspects of slavery, for example, the separation of slave families and never having received an education. Eventually, due to pressure from true abolitionists, on January 12, 1865, Sherman scheduled a meeting with the previously mentioned twenty Freedmen. The meeting was held to discuss precarious living conditions of newly freed Blacks; Sherman wanted to know Black Americans sentiments regarding the best method to address their predicament. Hoping to alleviate

${ }^{54}$ Billingsley, 1999, 36 
the new struggles that the majority of African Americans now struggled with, Sherman issued his Special Field Orders, No. 15. The order was meant to provide settlement to the more than 40,000 freed slaves, in addition to Black refuges on land expropriated from White landowners in South Carolina, Georgia, and Florida. Although, it was reversed by President Andrew Johnson later that same year. While the order was unsuccessful, Houston and the other twenty newly Freedmen were some of the main contributors to the conception of the idea. Another individual worth mentioning is James M. Simms, deacon in the First African Baptist Church. He was also a strong supporter of education and taught African Americans to read and write. Billingsley states that despite it being illegal to teach Blacks to read and write in the 1840s, Simms continued to do so. "Simms was whipped publicly when city officials discovered him. Undeterred, he continued teaching until he was fined $\$ 100 " .{ }^{55}$ Once fined, Simms refused to pay; therefore, he fled to Boston where he was ordained as a minister. After the American Civil War, he returned to Savannah where he became a member of the state legislature and "kept education as his highest priority". ${ }^{56}$ After the Civil War, African Americans worked hard and succeeded in ensuring that all Americans were allowed access to education. One example is the Pastor E. K. Love of the First African Baptist Church. Love was born a slave. He began preaching at the age of 18 . He was so influential that he eventually held multiple state and national posts; he also edited two newspapers. Moreover, he attended college at Morehouse College and graduated at the top of his class with a bachelor's

\footnotetext{
55 ibid

56 ibid
} 
degree in 1877. Love understood the importance of education and how it had the power to mobilize the Black community. He was a prime example of this very fact. It is very unlikely that without the education earned by Love that he would have been able to be pastor of a prominent Black Church, a political figure, and most importantly, influence the state Legislature to found the first college for African Americans in Georgia. ${ }^{57}$ African Americans understood that education was an important catalyst that would assist in dismantling the bondages of slavery and its effects. Not only would it break these captivities but it could also offer opportunities for socio-economic growth.

Black Churches were strong supporters of business and economic development within the Black community. For example, in 1875 a Black businessman named John $\mathrm{H}$. Deveaux founded a newspaper in Savannah Georgia called the Savannah Tribune. The purpose of the newspaper was to defend and elevate Black people, demolish racism, and create friendly relations with Whites. Billingsley states, "The churches were early and dependable supporters, users, and distributors of this newspaper." 58 But this is not all. Several Black Churches developed mutual aid societies, including the AMEC, when it founded the Free African Society. The Free African Society was a mutual aid society. Mutual aid societies demonstrates African Americans keenness to self-help and elevation through mutual assistance. The earliest Societies provided Blacks with different forms of health care and life insurance; care for the sick; the burying of the dead; and support for widows and orphans. As the Societies continued to flourish, they eventually began to

\footnotetext{
${ }^{57}$ Billingsley 1999, 41

${ }^{58}$ Billingsley 1999, 45
} 
endorse education and job preparation. These developments led to other developments such as Black-owned insurance companies, which later turned into Black-owned banks. These series of events ultimately had an affect on the modern day Black Church and its interest and dedication to supporting Black-owned banks, which will be discussed in chapter three.

The Black Church focused on both educational and economic endeavors. Throughout history, the Black Church has been involved in activities such as student sitin movements, activities, and initiatives created to mobilize Blacks. The Black Church stood at the forefront of the Black cause and understood its role as both a spiritual and social agent. Billingsley shows that some churches have characteristics that will make it more likely to become an activist church. Furthermore, he asserts that the Methodist denomination is most likely to be an activist church and that $77 \%$ of Methodist churches conduct community outreach programs. ${ }^{59}$ Overall, Methodist Churches are more likely than all other churches to be activist churches. The Baptist church, with $65 \%$ likelihood to be an activist church, is the closes in likelihood to the Methodist church, to participate in outreach programs. Billingsley proclaims that churches of this nature are more likely to participate in outreach programs than others. There are seven characteristics that are determinants of a churches' activism: denomination, church age, size, membership composition, ownership of church building, number of clergy, and other paid staff. ${ }^{60}$ Billingsley writes, "In sum, churches that are characterized by more of the above

\footnotetext{
${ }^{59}$ Billingsley 1999, 95

60 ibid.
} 
resources are much more likely to engage in community outreach programs than churches with fewer of those resources." ${ }^{\prime 1}$ This is an important claim and especially relevant to my topic. The AMEC originated from the Methodist denomination. This explains the Black Methodist congregations propensity to socially intervene on behalf of its communitythe Black community. Methodist scholar, Dr. Joseph M. Shopshire of the Wesleyan Theological Seminary in Washington, D.C., beliefs that due to the importance placed on grace, scriptural holiness, free will, justification, sanctification, and perfection, that Methodists were predisposed to an acceptance of outreach ministries as an important aspect of the faith response. ${ }^{62}$ Shopshire goes on to state, "Benevolent efforts, mission and service through practical forms of caring for others have from early times been embraced as a necessary response of the life of holiness. ${ }^{93}$ Reverend Ronald Brailsford, at the time assistant pastor at the Big Bethel AMEC in Atlanta, believes in the primacy of Methodist churches in regards to social reform. For him, social reform was the sole reason for founding the AMEC; there are disagreements surrounding the extent, but it is singularly agreed that it is a component of the AMEC doctrine.${ }^{64}$ Eventually, Brailsford became pastor of the Bethel AMEC in Columbia, South Carolina. In his appointment, he led an energetic social program campaign dealing with housing, substance abuse, employment, and especially education. Programs such as the aforementioned are only but

${ }^{61}$ ibid.

${ }^{62}$ Joseph M. Shopshire, "The Methodist Church and Community Outreach," in Billingsley et al., Tradition and Change (unpublished, 1992)

${ }^{63}$ ibid

${ }^{64}$ Billingsley 1999, 45 
a few examples of the AMEC's activeness in community outreach programs. My research will concentrate on the types of outreach programs offered by the AMEC historically and currently and assess the effectiveness of them. It will also examine education and the importance pinned to it by AME leaders.

The AMEC's history is centered upon mobilizing the Black community. Education was used as a catalyst to improve African Americans' socio-economic situation. The AMEC's involvement in the education of Blacks can be divided into two main periods. David Childs declares that, "from its founding in 1816 through the end of the Civil War in 1865 the church was largely focused on the abolition of slavery and overcoming racial oppression." 65 He then compares this to its outreach programs from 1865 to 1893 . Once Bishop Payne passed away, the church focused mainly on a type of liberation that understood Black self-agency, as a prerequisite to achieving socioeconomic advancement America. Therefore, I will focus on these two time periods in order to illuminate the activity of the AMEC in the Black community. I will address the issues that the church was confronted with; the issues faced by Blacks; and how the church used education to combat them all.

Historically, the AMEC believed that education was the tool in which African Americans were to use in order to liberate themselves. Richard Allen, the founder of the AMEC, clearly saw the importance of education. It provided the Black community with a form of autonomy. Education had many purposes, but one reason it was initially so important to Allen was because it had the ability to provide Blacks with independent

${ }^{65}$ Alexander, Richard Allen: The First Exemplar of African American Education, 118 
access to the Bible and gave ministers the ability to read, interpret, and lead effectively. This would not have been possible without a basic education. Self-education therefore had a utilitarian purpose.

The AMEC originated in a racist climate that restricted the educating of African Americans. According to David J. Childs, "White fear of slave escapes and revolts began to heighten in the United States and laws were passed in the South making it illegal for African Americans to obtain an education... This happened because pro-slavery advocates understood that if slaves learned to read it would not be long until they began to think about freedom and liberation" ${ }^{66}$ Furthermore, he asserts that the south implemented political and social obstacles in order to prevent Black progress. In The Black Church and African American Education: The African Methodist Episcopal Church Educating for Liberation, 1816-1893, David Childs states, "Many of the laws in the antebellum south were designed to reinforce and perpetuate the system of slavery". ${ }^{67}$ In addition, Albert J. Raboteau shows that orthodox Christianity itself was a doubleedged sword - its egalitarian elements frequently motivated a longing for worldly as well as spiritual freedom, as shown by the religious background of Nat Turner's insurrection and various slave conspiracies. Educating Blacks was so prohibited that if one was caught educating an African American in Mississippi, one could be jailed or whipped with "thirty-nine lashes". ${ }^{68}$ A slave named William McWhorter stated, "Dey jus' beat 'em up

${ }^{66}$ Childs, The Black Church and African American Education: The African Methodist Episcopal Church Educating for Liberation, 1816-1893, 6

67 ibid, 46

${ }^{68}$ Laws of the State of Mississippi: Passed at the Sixth Session of the General Assembly 
bad when dey cotched 'em studyin' readin' and writin." ${ }^{69}$ Initially, Blacks viewed education as giving them access to reading the Bible. Raboteau asserts, "The thirst of slaves for religious education led them to sneak lessons whenever they found a teacher". 70

When the educating of Blacks was normalized, the institutions built to educate them were either inadequate or insufficient. Though there were government programs such as the Freedman's Bureau and various state boards of education that established small schools for African Americans in some communities, they were often closed quickly and the resources used were often inadequate. ${ }^{71}$ Though inadequate as they were, this did not stop ex-slaves from seeking out educational institutions after slavery ended. In his book Slave Religion, Albert Raboteau writes, "The reverence which they held for the Bible moved many ex-slaves to flock to schools set up by missionaries after freedom came". ${ }^{72}$ It is in this unfavorable environment that the AMEC stood at the forefront of institutions set on educating the Black community.

Richard Allen founded Bethel Church in 1787, prior to his founding of the AMEC. Subsequently, Bethel Church did not officially become a member of the AMEC until the AMEC was established in 1816. Therefore, Bethel Church, established prior to the founding of AMEC by Richard Allen, was the first institute to become a member of

${ }^{69}$ Raboteau, Slave Religion, 239

70 ibid

${ }^{71}$ Anderson, 1988 qt. in Childs, The Black Church and African American Education: The African Methodist, 6 Episcopal Church Educating for Liberation, 1816-18936

72 Raboteau, Slave Religion, 240 
the AMEC. In both 1787 and 1816, the founder and congregation of Bethel Church understood its purpose. Bethel Church was not only a place of worship and a place of assembly but also a place where both secular and sacred goals would be aspired to. Bethel Church housed the first school in America established by Blacks to teach Black children. "The opening of a day school for African children in 1795 by Allen in the Bethel Church set a precedent as it was the first school in America to be established by Africans for African children. The teaching of reading and writing to African children in a formal school atmosphere by Allen was the beginning of the historic use of the African American facility as an educational and religious institution. ${ }^{73}$ Moreover, Alexander asserts, "Allen was a man who had the capacity to fuse both theory and practice, the secular and the religious. This fusion aided his attempt to organize the life of the Africans, which proved to be a most significant and historical endeavor". ${ }^{74}$ These quotes illustrate the educational initiatives of Richard Allen, the founder of the AMEC. From the church's inception and even before it, the organization's primary goal was to obtain an education, primarily focusing on reading and writing, in order to understand the Bible and then transmit the biblical knowledge to the secular world. The denomination's goal, however, evolved; it strove to achieve educational equality for Blacks. In many ways the implementation of reading and writing lessons was meant to promote Blacks ability to read and interpret the Bible without needing the assistance of others, neither Black nor white. Although not his initial plan, Allen would begin to establish AMEC's greater purpose - achieving socio-economic equality through education. Allen's decision to

\footnotetext{
${ }^{73}$ Alexander, Richard Allen: The First Exemplar of African American Education, 100 74 ibid, 19
} 
establish a school, funded by the AMEC, would have greater implications in the future, effecting the manner in which the AMEC's religious leaders viewed education, the amount of importance they placed on it, and the energy they would exert to ensure that Blacks attained it.

From its inception, the AMEC was committed to socially intervening in order to help its community's socio-economic situation and thus championed education as a catalyst to this goal. Sarah Coprich Johnson in The Role of the Black Church in Family Literacy asserts that in the nineteenth century the AMEC believed strongly in social reform through education and therefore endorsed it; she goes further and stresses the significant role the Black Church had in educating African Americans. ${ }^{75}$ Many individuals worked collectively to establish education as a religious and social requirement, but there were three individuals that pioneered the education enterprise.

\section{Pioneers of Education within the AMEC}

There are three AMEC members that are very important when discussing the educational endeavors of the AMEC. Richard Allen, Daniel Payne, and Richard Wright Jr., were significant figures in the denomination. Richard Allen, the founder and first Bishop of the denomination contributed greatly to the success of the AMEC because he ensured that it maintained its Methodist roots and that throughout every endeavor that its core theological values were maintained. According to Shannon A. Butler-Mokoro in her dissertation Racial Uplift and Self-Determination: The African Methodist Episcopal Church and Its Pursuit of Higher Education, "Richard Allen and his contributions are

${ }^{75}$ Johnson, The Role of the Black Church in Family Literacy, 1999 
important because it is through him that the African Methodist Episcopal Church maintained its Methodist roots and philosophy and through Allen that the church remained committed to promoting Christian values in every venture it undertook, including education". ${ }^{76}$ It is because of Allen that the church sought to enhance not only the spiritual and moral lives of Blacks. Richard Allen was one of the primary founders of the Free African Society in 1787, from which, the AMEC originated. The Society's sole purpose was to provide mutual aid assistance. What's worth noting about the society is its focus on secular matters such as education and economics. The Preamble of the Free African Society required free Africans and their descendants to pay a monthly subscription to support members in the society who may need assistance. ${ }^{77}$ Moreover, the following statement concerning education was included, "and we apprehend it to be necessary, that the children of our deceased members be under the care of the Society, so far as to pay for the education of their children, if they cannot attend the free school; also to put them out apprentices to suitable trades or places, if required". ${ }^{78}$ This evidence is important because the AMEC developed from the Free African Society, and thus its initiatives and principles are similar to those of the Society. AMEC's focuses on both economic and educational issues are results of both the Methodist Episcopal Church and the Free African Society. Though during this time period education was thought of primarily within the context of religion, it opened doors for the path that the AMEC

\footnotetext{
${ }^{76}$ Butler-Mokoro, Shannon. Racial Uplift and Self-Determination: The African Methodist Episcopal Church and its Pursuit of Higher Education, 111

${ }^{77}$ Preamble of the Free African Society, April 12, 1778

78 ibid
} 
would eventually take with the appointment of Bishop Payne. For example, the desire to put Black youth into a position where they could learn a trade illuminates the importance that the AMEC placed on Blacks' need to be self-sufficient. However, for Allen education was meant to provide the Black community with independent access to reading the Bible so that they could lead a religiously righteous life. The AMEC and the outreach programs created were meant to create a place of not only worship, but also a place of community, betterment, and equality. The focus of the Free African Society on economics and education addresses prevalent issues in the Black community and attempts to create ways to fix the problems. Not having a basic education or a trade meant the continuation of the current predicament of Blacks; without it, there was no way out of the legacy of slavery and its effects. Although with an education or a trade, opportunities became available for Blacks. The upward mobility of the Black community depended on the opportunities offered by education and financial stability. While these were the initiatives of the Free African Society, the AMEC did not seamlessly blend religious vigor and social intervention until Bishop Payne was elected bishop. However, the Free African Society did give free Africans support in social and economic affairs. It was only a matter of time before the union of both came into fruition.

Richard Allen, the first bishop of the AMEC, served from 1816 until his death in 1831. Because he was the first Bishop of the AMEC, Allen definitely played a part in the construction of the Doctrines and Disciplines. The Doctrines and Discipline of the AMEC was the first Discipline published, in 1817, by the AMEC; it is a definitive guide to the history, beliefs, teachings, and practices of the early AMEC. These articles shed light on Allen's interpretation of Christian life and duty. One important article blends the 
life and duty of a Christian with its inseparable educational aspect. One cannot live a proper Christian life without being able to read the message of God and his commandments. The doctrine can easily be altered, especially in the times prior to Emancipation, to benefit the oppressor oppose to the practicing Black Christian trying to please and worship his God. Therefore, being literate is a staple of being Christian. Article five "The Sufficiency of the Holy Scripture for Salvation," clearly speaks to the indivisible relationship between education and religion for the AMEC. ${ }^{79}$ The article states, "Holy Scripture containeth all things necessary to salvation: so that whatsoever is not read therein, nor may be proved thereby, is not to be required of any man, that it should be believed as an article of faith, or be thought requisite or necessary to salvation. ${ }^{80}$ This quote exemplifies the sentiment felt by Blacks about the Bible, the attachment they felt to the gospel, and their use of it to live a life worthy enough to please God. This is not surprising being that it was the gospel that created community amongst Blacks and the use of the hymns and prayers to God that helped them survive the hardships of slavery. The first Bishop was responsible for beginning Sunday schools to impart biblical knowledge. For Allen, education was thought of in the context of religion and salvation. Richard Allen, through the Free African Society, implemented practical measures to assist the Black community with its socioeconomic struggles; however, he did not transfer those initiatives to his church quite as effectively as he did with the

${ }^{79}$ Butler-Mokoro, Racial Uplift and Self-Determination: The African Methodist Episcopal Church and its Pursuit of Higher Education, 131

80 The Doctrines and Disciplines of the African Methodist Episcopal Church, Cunningham, 1817, 15-17 
mutual aid society. Even though during Richard Allen's time he did not extensively expand upon practical measures of education in order to promote Black equality and stability, in the manner that Daniel Payne would, his efforts definitely put the AMEC in the right direction to work towards and to achieve that very goal.

When Richard Allen and Absalom Jones formed the Free African Society they envisioned the society as an interdenominational foundation that promoted Black progress. When the Society was new and still small in size, Allen hosted meetings for the Society inside of his home. He was devoted to the advancement of the livelihoods of the Black community. He was committed to the Society for two years, before resigning because of the gradual shift from interdenominational practices to Quaker religious norms such as silent prayer, which was incompatible with the AMEC outward expression of spirituality. Richard Allen efforts with the Free African Society show his interest in the upward mobility of the Black community. It shows the desire to offer Blacks the means and opportunity to educate and then to support themselves.

Daniel Payne, elected the sixth Bishop in 1853, would continue to promote the Christian values promulgated by Allen, in addition to becoming the first Bishop who was a vocal proponent in support of education. Payne's involvement with education differed from that of Richard Allen. While Richard Allen planted the seed of education, Payne watered it. Payne recognized the innate practicality of education and ventured to make it applicable to the Black quest for socio-economic equality. Payne believed that knowledge was one of the most valuable resources available. As a child, a wealthy planter told Payne, "Daniel, do you know what makes the master and servant? Nothing but superior 
knowledge — nothing but one man knowing more than another" ${ }^{81}$ It was this statement that inspired him to delve into books and to dedicate himself to education. This statement also fueled his passion for education as a Bishop.

The sixth Bishop was overt and open with his views of incorporating more education into the Black community through the church. Originally, the AMEC discussed education and its spiritual importance, but its progression beyond that was slow. Black Christians valued education, primarily as a tool that gave them unlimited access to the Bible. However, the connection between education and socio-economic betterment was developing slower than what the sixth Bishop preferred. Black Christian's concept of education only gradually progressed from Bible reading to more comprehensive education and vocational training. Daniel Payne's era marked a change in the AMEC and pointed it in a new direction. He believed that the church was capable of accomplishing more than what it currently had in regards to the implementation of education. $\mathrm{He}$ observed that the church, though having already implementing educational programs, had not made substantial progress towards educating its ministers nor the youth of its congregation. Therefore, the Bishop reflects on this in 1825 and declares: "We find no traces of any efforts for literary improvement among ministers, nor the education of the rising generation through any agency of the Conferences. The absence of any efforts for literary improvement among the ministers, and the want of any means of education among the rising generation, and the total absence of Sunday-schools, are all to be regretted" ${ }^{82}$ It is evident that for Payne education was a prerequisite to the elevation of

${ }^{81}$ Payne, Recollections of Seventy Years, 267-277

82 ibid, 52-53 
the Black race. Educating the ministers who at the time, and still arguably so, were the leaders of their community would benefit Blacks. Educating the youth of the community would create a new foundation that would subsequently lead to a new narrative for Blacks. Instead of being an illiterate and inferior race, one that was unable to support themselves due to the effects of colonization and slavery, they would become a literate and equal one. With education they would break the chains of servitude. In 1834, the Philadelphia Conference adopted the following resolutions; "It shall be the duty of every minister who has charge of a circuit or station, to use every effort to establish schools wherever convenient and to insist upon parents of children sending them to school". ${ }^{83}$ Although the resolution was passed nine years after Payne's statement, Payne prompted the leadership of the AMEC to begin to think of education as something requiring more vigor and focus. Butler-Mokoro believes that it is in this way that both Daniel Payne and the AMEC "acted as a beacon of light for the future". ${ }^{84}$ This step by the AMEC was one of the many first steps towards becoming both a spiritually and socially inclined church that it is today.

Payne was one of the first known Bishops to create a curriculum for the ministry of the church. He presented this course of studies in 1841. In Daniel Payne's History of the African Methodist Episcopal Church, the church resolved:

\footnotetext{
83 ibid, 98

84 Butler-Mokoro, Racial Uplift and Self-Determination: The African Methodist Episcopal Church and its Pursuit of Higher Education, 147
} 
The elders and deacons of the Connection make use of all the means in our power from henceforth to cultivate our minds and increase our store of knowledge. Then, second, that we recommend to all our elders and deacons, licensed preachers and exhorters, the diligent and indefatigable study of the following branches of useful knowledge: English Grammar, Geography, Arithmetic, Rollin's Ancient History, Modern History, Ecclesiastical History, Natural and Revealed Theology. ${ }^{85}$

It is in this era of the AMEC that we can see an evident turn in the views of education and its importance. While Richard Allen appreciated education and its spiritual capabilities, Daniel Payne admired education and understood its full capacity in piloting the Black community. It would seem evident that another individual would rise to the occasion in the Black progressive movement in the wake of the socially active Payne.

In spite of the division of the country, separated between supporters of slavery and abolitionists, the denomination strove to establish an institute that was capable of liberating Blacks' minds and bodies. Payne took on the task of running the institute so that he may improve "the intellectual and moral condition" of African Americans. ${ }^{86}$ However, I believe that it is safe to say that the institution also improved African Americans socio-economic position in society. The statement is made based on the courses offered by the university. Not only did the university provide students with a classical education, but it also offered teacher training. Therefore, students were being offered both a liberal arts and practical education. They were enlightening their minds and developing a skill, which would help support them financially. AME literature of the time held a common notion of the Christian scholar. According to John M. Henderson,

\footnotetext{
${ }^{85}$ Payne, Daniel Alexander. History of the African Methodist Episcopal Church, 141

${ }^{86}$ Payne, 423
} 
the Christian scholar "was a person that had moral piety, intelligence, and was motivated to pursue the same careers and jobs that were available to the main culture of society" ${ }^{87}$ The themes are consistent. The goal of the AMEC was to improve the overall condition of African Americans. Each venture that it set out on was to achieve liberation. The definition of liberation has changed over time depending on the historical climate. As previously stated, throughout history, the meaning of liberation is varied and numerous. However, it is undeniable that with every new definition the AMEC adapted each time. The institution was constantly evolving and progressing. According to Kenneth Jost, "Before the Civil War, African Americans, whether slave or free, were restricted from higher education by law in the South and — with limited exceptions — by social custom elsewhere...Five of today's historically black colleges can trace their roots to the antebellum period, but only one - Wilberforce University in Ohio, founded in 1856 by the African Methodist Episcopal Church — actually awarded baccalaureate degrees before the Civil War". ${ }^{88}$ The AMEC was an educational pioneer of its time for African Americans. It constantly challenged the norm and sought to discover new and innovative ways to propel the Black community. After the Civil War, Wilberforce continued to move forward. The university was able to liberate Blacks spiritually by focusing on moral piety while also offering them a comprehensive education. Its focus was industrial and liberal. An industrial education prepared Blacks for a specific industry, preparing them to

${ }^{87}$ Henderson, 338-345

${ }^{88}$ Jost, Kenneth. "Black Colleges." CQ Researcher13, no. 43 (December 12, 2003): 1045-68. http://library.cqpress.com/cqresearcher/cqresrre2003121200. Kenneth Jost is a honors graduate of Harvard College and Georgetown Law School who has covered legal affairs as a reporter, editor, and columnist for more than fifty years 
use subjects such as math, reading, and various others to be able to apply in a practical way. This industry perspective proved to be beneficial financially. A liberal arts education was also taught to offer individuals a broad knowledge and one with transferrable skills. As stated by David Childs, "The challenge for freedom after slavery was to acquire full citizenship status (political, social, and economic rights)". ${ }^{89}$ In order to acquire this citizenship, the community had to be knowledgeable in all areas so that they would be prepared to step into society fully and so that they would be educated enough to support themselves financially and detect when others were hindering their socio-economic aims. The education at Wilberforce gave them the necessary tools needed for achieving this goal.

Building on the work of these two early leaders, Richard R. Wright Jr. (18781967) would give further shape and definition to the need for Black education. An AMEC minister, sociologist, and social worker, Wright made significant contributions to the Black community during the Progressive Era and serves as an example for contemporary ministers, intellectuals, and secular workers. He used his position to systematically engage the social issues that plagued his community. Wright's actions were inspired by his theological and sociological views and training. It was through the AMEC that Wright was able to provide hope to the masses. Furthermore, he made it his life's goal to merge Christian values and ideals with social uplift. Wright is a product of three factors: his family, education, and faith.

${ }^{89}$ Childs, 110 
Wright was born on April 16, 1878, Cuthbert, Georgia. Both of his parents attended college at Atlanta University and taught in Cuthbert. ${ }^{90}$ Wright's mother, Lydia Howard Wright, was able to read and write; once Blacks were emancipated, she taught the freedmen how to do the same. Her parents had valued education and took every measure possible to ensure the best education for their children. His grandparents did well for themselves and made a great impact upon the future AME pastor and bishop. They were able to read, write, and had basic computational skills. Furthermore, they owned their own property, multiple horses, among other things. This expresses the importance placed on socio-economic stability by African Americans in the $19^{\text {th }}$ century; identical to Blacks' aspirations of the modern times, having an education and financial prowess was equally important then as it is now. This was a challenging achievement for Blacks in the $19^{\text {th }}$ century and in many ways it still is. Richard Wright Sr., Wright's father, also believed strongly in education. Wright Sr. was born into slavery on May 16, 1855. Once African Americans were emancipated, Wright Sr.'s mother moved herself and her son to Atlanta Georgia where he attended and graduated near the top of his class from Storrs School, an institution established by the American Missionary Association. In 1876, Wright Sr. became the valedictorian at Atlanta University's first commencement ceremony. Over his lifetime, he studied at a number of institutions such as Harvard, Columbia, the University of Chicago, Oxford University, and the University of

${ }^{90}$ Fleming, George James, and Christian E. Burckel. Who's Who in Colored America, Supplement: An Illustrated Biographical Directory of Notable Living Persons of African Descent in the United States, 1950, 589; Haynes, Elizabeth Ross, The Black Boy of Atlanta, 1952, 48 
Pennsylvania. ${ }^{91}$ In addition to his educational accomplishments, he founded the Georgia State Industrial College for Colored Youth in Savannah in 1891. The institute is now known as the Savannah State University. From 1891-1921, he served as its first president. He created a curriculum that focused primarily on the classical liberal arts and vocational education. In 1891, when the institution opened, only eight students were enrolled. At the end of Wright Sr.'s tenure, there were over 400 students enrolled. In 1898, Wright Sr. served as a paymaster in the Spanish American War and held the title of the highestranking African American officer during a war. ${ }^{92}$ Wright Sr. was also a businessman and opened a bank in Philadelphia with Wright Jr. and his daughter Lillian. The business was successful. The bank survived the Great Depression and continued to grow. In 1957, it had assets of \$5.5 million. Wright Sr. was quite established and provided his son with an upper class education and lifestyle. It is in this familial background that Wright Jr. grew and began to develop all of his concepts of education, self-help through education and economics, and racial uplift.

Richard Wright's family was significant but his education played an even greater role in the man he would eventually become for his community. The first college that Wright attended was Georgia State College. His father was the president of this college. Though the university focused on technical skills, it also offered students classical courses in Greek and Latin. It was from this institution that Wright would later go on to

${ }^{91}$ Meakin, Kate. "Richard R. Wright Sr. (1855-1947) • BlackPast." BlackPast. January 31, 2019. Accessed March 22, 2019. https://www.blackpast.org/african-americanhistory/wright-richard-r-sr-1855-1947/.

92 ibid. 
graduate with a degree in $1898 .{ }^{93} \mathrm{He}$ received the first baccalaureate degree awarded by the college. The second college that Wright attended was the Divinity School at the University of Chicago. This university had the greatest educational impact on him. It was here that Wright learned about the Historical Critical Method of Biblical Studies. The concepts learned had such a great influence on him that because of it he committed himself to the Social Gospel. The Social Gospel is the practice of Christian faith not just as a call to personal conversion but to social reform. It is this practice of Christian faith to which, he would devote his life. He earned both a Bachelor's of Divinity Degree and a Masters in Biblical Languages from the University. In total he earned three degrees from universities. It was at the University of Chicago that Wright met George Edmund Haynes, the founder of the Urban League, a nonpartisan civil rights organization that advocates on behalf of African Americans and against racial discrimination in the United States. Wright's relationship with Haynes and other individuals led him to focus on sociology.

In order to study sociology, Wright attended the University of Pennsylvania in Philadelphia. It was at the University that Wright was able to hone in on his academic pursuits, which would later mean a great deal to the Black community and its social uplift. He chose to debunk many of the theories proposed by W.E.B. DuBois regarding the "Negro Problem." In his study The Negro in Pennsylvania he addresses and discredits many of the myths about African Americans. He redefines the "Negro Problem" as a lack

${ }^{93}$ Fleming and Burckel, 1950, 589 
of knowledge and understanding on the part of the majority culture. ${ }^{94}$ While DuBois viewed the "Negro Problem" as a community plagued by crime, ignorance, and laziness, Wright views it quite differently. Wright seems to focus more upon the effects of Blacks living in a country where the majority culture has a negative view of them, which in turn bars them from gaining access to the same necessities of life as the majority culture. ${ }^{95}$ As one researcher states, Wright recognized "poor living conditions and lack of access to economic opportunity and the attitude and ignorance of the White culture as the major factors of the 'Negro Problem'". 96 Wright fervently believed "that condition which is peculiar to the Negroes, and common to them - is rather found in the attitude of the White race toward the Negro; an attitude of majority which seeks to shut out a minority from the enjoyment of the whole social and economic life". ${ }^{97}$ These are the ideas of the AME minister that inspired him to merge the spiritual and social needs of his congregation and community.

The last factor after education, which also influenced Wright, was his faith. Just as vital as family and education in developing the mind and spirit of Richard Wright Jr., were his religious beliefs. Wright was devoted to his mother's denomination, the AMEC. The AMEC is significant in further shaping Wright because upon its founding and still so

\footnotetext{
${ }^{94}$ Wright, Richard R. The Negro in Pennsylvania; a Study in Economic History, 1969

95 Wright, 1912; 1969

${ }^{96}$ Modesto, Won 't Be Weighted Down:" Richard R. Wright, Jr.'s Contributions to Social Work and Social Welfare, 2004

97 Wright, 1912; 1969
} 
today, its primary focus has been to mobilize the Black community through self help. ${ }^{98}$ Wright's faith would lead him to also study religion and would later call him into the ministry as a Bishop. Wright's desire to debunk the plaguing myths surrounding the Black community and to elevate the community as a whole led him to use his position within the Church to assist his people and develop leadership for future generations. His keenness for the Social Gospel was motivation to merge the spiritual with secular. Thus, Wright declared, "I have devoted myself to the Christian ministry, as I was early convinced that building the spirit of the people is the most important thing". ${ }^{99}$ However, he coupled his spiritual aspirations with social reform by actively working to improve his community and provide opportunities for education and social uplift through self-help.

Wright was devoted to confronting the educational and economic problems of African Americans. He studied what was termed the "Negro Problem" to understand what truly was confronting African Americans. He sought to go past popular beliefs and addressed the root of the problem. The problems that Blacks were confronted with were becoming more and more attached to class. Before Emancipation, Blacks were controlled directly. After Emancipation, Blacks were controlled covertly through economics. By denying Blacks jobs, even if they were able to obtain a good education, maintained their lower class position. Having to work low wage jobs required an increase in the amount of time one was at work. Consequently, this led to two negative results: many Blacks were discouraged to pursue an education and many Black children would be left unsupervised

\footnotetext{
98 Alexander, Richard Allen: The First Exemplar of African American Education, 118

99 Wright, Richard R. 87 Years behind the Black Curtain: An Autobiography. Philadelphia: Rare Book, 1965.
} 
due to a lack of parental guidance in turn leading to crime. This reality created a vicious cycle, which led to the social enslavement of Blacks. This cycle continues today, despite the growing percentage of African Americans earning various college degrees, there remains a financial discrepancy between Blacks and whites that have the same level of education. Blacks are strategically being denied access to higher paying jobs. This will be further discussed in chapter three.

Wright wanted to break the cycle and enter a new and prosperous realm. During his time, there were two competing ideas as to how to assist the Black community in achieving upward mobility through education and economics. There were many scholars that debated on the best method to break the cycle of the Black predicament, but Du Bois and Washington were the most renowned. DuBois felt that in order to assist the Black community in achieving social equality that the "Talented Tenth" would need to be developed. ${ }^{100}$ This method believed in targeting the elite of the race and letting them set the example that would eventually lead to the improvement of the entire race by pulling them upward. Contrastingly, Booker T. Washington viewed classical liberal education as less important and chose to focus primarily on technical training. ${ }^{101} \mathrm{He}$ had a grassroots approach and felt that for the Black community to gain social liberation they would have to take a bottom up approach. Wright's ideology concerning the betterment of African Americans, lay somewhere in between both DuBois and Washington's philosophies; he

${ }^{100}$ DuBois, W.E.B. The Negro Problem. A Series of Articles by Representative American Negroes of Today. Contributions by Booker T. Washington ... W. E. B. Dubois, P. L. Dunbar, C. W. Chesnutt, and Others.

101 ibid 
believed that classical liberal education and technical training were both equally important. Modesto proclaims, "Philosophically, Wright fell between DuBois and Washington, actively advocating and creating opportunities for employment for all African Americans as well as encouraging and creating opportunities for the educational uplift of his people... uplift, for Wright, could occur through manual labor and or classical liberal education, but it was primarily a product of Negro self-help". ${ }^{102}$ All in all, Wright believed that social uplift was a result of Blacks helping themselves. It was necessary for African Americans to come together as a community and strive to find ways to better their own community without the assistance of outsiders. It is in this way that the community would gain independence and stop relying on its former enslavers.

The beliefs held by Richard R. Wright Jr., would lead him to take great interest in social work and social welfare. Wright was involved in several educational and economic endeavors that were meant to benefit and serve as a catalyst to his community. For example, one of his earliest attempts at social work was when he worked at the Eighth Street Settlement House. One of his duties included educating the boys who worked various jobs and were unable to attend school due to their workload. This connects back to his view that both technical training and classical liberal education were essential. The need to support oneself by having to work more due to the low wage jobs offered to Blacks often put Blacks in a position where it was almost impossible to consider education as a possible venture. It was at the Eight Street Settlement House that Wright proposed that Settlement House start a bank. He saw a need for Black homeownership in

\footnotetext{
${ }^{102}$ Modesto, Won 't Be Weighted Down:" Richard R. Wright, Jr.'s Contributions to Social Work and Social Welfare, 2004
} 
the community. He presented the idea to the benefactor of the Settlement. Subsequently, the Eighth Street Settlement House led to the development of the Eighth Ward Settlement Building and Loan. ${ }^{103}$ This establishment was progressive and stood as a symbol of pride for the community. It stood as a symbol of self-help. In the $21^{\text {st }}$ century, the AMEC partners with Black Wealth 2020, which is an organization that has financial goals that are almost identical to that of the Eighth Ward Settlement Building and Loan. Black Wealth 2020 will be further discussed in chapter three.

After his work at the Eighth Street Settlement House, he gained recognition and more opportunities opened for him to help his community help itself. Wright developed an enriching relationship with John T. Emlen. The relationship would result in another prosperous opportunity for African Americans on behalf of the AME minister. The Armstrong Association was established and sought to help southern migrants who recently moved to the north. The association had two purposes. The purposes were educational and economic. Wright was commissioned with working directly with the migrants as the first field secretary. He was responsible for both writing the constitution of the organization and securing work for the North's new citizens. Furthermore, Wright also created the Colored Mechanics Association, which was an organization whose goal was to help migrants find work in a field in which they had acquired a skill in and were trained for. ${ }^{104}$ Unfortunately, during his two years with the Association, Wright's philosophy of self-help conflicted with the association's president's ideology of social

${ }^{103}$ Wright, 1910, 1965

${ }^{104}$ Modesto, Won 't Be Weighted Down:" Richard R. Wright, Jr.'s Contributions to Social Work and Social Welfare, 2004 
service. The president felt that it was important to support the south solely through charity, which directly opposed Wright's views. Consequently, Wright ceased to work with the organization. Subsequently, he was chosen to work as one of the most influential and significant figures in the AMEC. Later, according to Kevin Modesto, Wright functioned as the literary organ of the Christian Recorder since he was elected as its editor. ${ }^{105}$ This position was fundamental because it allowed him to use one of the oldest existing periodicals, first published in 1854 and by African Americans, to express his views regarding the Social Gospel. As its tenth editor, he was able to further promote and advocate for social reform. According to Shannon A. Butler-Mokoro, "the recorder was the one place in which the Church responded to the socio-political debates and where proponents of education were given the opportunity to express their desires and to promote the benefits of education". ${ }^{106}$ From 1909 to 1928 , Wright altered his approach to the problematic situation of African Americans. His hands-on approach with Black migrants and helping them to find employment after having moved from the south to the north in search of a better socio-economic situation, was changed in order to directly communicate with a larger population of African Americans as the editor of Christian Recorder. ${ }^{107}$ In Sparks From the Anvil of Oppression, Robert Gregg points out that Wright was able to advocate for Southern migrants as editor of the Christian Recorder. ${ }^{108}$

\footnotetext{
105 ibid

${ }^{106}$ Butler-Mokoro, 181

107 ibid

108 Gregg, Robert. Sparks from the Anvil of Oppression: Philadelphias African Methodists and Southern Migrants, 99
} 
He was able to stress the importance of securing employment and education for them. For Wright, self-help was actualized by way of education and economics.

In addition to publishing prolific research and writing, Wright made his work relevant to real life in a very practical way. For instance, all during the time he was editor of the Christian Recorder, he remained involved in banking along with his father. The bank was quite successful and became one of the leading Black owned banks in the nation. It offered real opportunities for Blacks in America and helped further promote the concept of black self-help that the AMEC promoted so often. ${ }^{109}$ The bank, Citizens and Southern Banking Company, helped to launch dozens of Black businesses and in turn helped Black business owners succeed. When the bank became a trust company it provided Blacks Philadelphians the loans required to purchase homes. Black banks were important and remain so still today because they stand not only as financial institutes but statements of African Americans ability to succeed in the financial world. The topic of the contemporary AMEC's involvement with Black banks will be expanded upon in chapter three. According to M.R. Davie, "The Negro bank is more than a financial institution; it is a symbol of the Negro's aspirations to enter commercial life of the nation and a mark of his faith in his own ability and competence". ${ }^{110}$ The creation of the Black bank by Richard Wright exemplifies the denomination and its leaders tendency to actively promote social reform for its community. This is one of many ways in which the

${ }^{109}$ Haynes, Elizabeth Ross. The Black Boy of Atlanta, 1952 Meier, August. Negro Thought in America: 1880-1915; Racial Ideologies in the Age of Booker T. Washington, 1969.

110 Davie, Maurice R. Negroes in American Society, 1949. 
AMEC has shown its aspiration to meet the social needs of its community. As Kevin Modesto states, "These economic ventures were instruments of self-help and hope."111

In 1928, Wright returned to ministry as pastor of Ward AMEC in Philadelphia. In this position, Wright continued to do what he previously did for the community, apply Christian principles to real life challenges. Wright was constantly looking for different ways to advance the African American community. Therefore, when the AMEC elected him to be president of its university, Wilberforce University, he accepted. Wilberforce University was founded with the objective of educating African Americans. Daniel Payne is credited with establishing Wilberforce University under the AMEC once it was purchased from the M.E. Church. But Richard R. Wright Jr. took it a step further and put it on the track to accreditation. During Wright's position of presidency over Wilberforce University, there were two separate boards of control. The debate between Booker T. Washington and W.E.B. Du Bois had a direct affect on Wilberforce University. Whether or not African Americans should receive a Liberal Arts education or an Industrial education was a debate that the two boards of control had differing opinions on. This in turn, had an effect on the Wright's initiatives. Prior to Wright's presidency, in 1887 , the Ohio legislature established a Combined Normal and Industrial Department at Wilberforce University. The purpose of this was to provide Ohio's Blacks with additional training. ${ }^{112}$ The educational facility was created alongside Wilberforce University. The AMEC sponsored Board of Trustees governed Wilberforce University and the College of

111 Modesto, Won 't Be Weighted Down:" Richard R. Wright, Jr. 's Contributions to Social Work and Social Welfare, 2004

112 Dortch, Timothy Aldwin. The Development of Curriculum and Instruction at Wilberforce University from 1941 to 1947, 36 
Liberal Arts, while the State Board of Trustees controlled the Combined Normal and Industrial Department. Unlike the former, the latter had no voice in the presidential election process. Additionally, the two programs were financially supported differently. Wilberforce University and its College of Liberal Arts relied solely on the funding of the church district contributions and student tuition and fees. On the other hand, the Combined Normal and Industrial School was provided with the necessary money to construct buildings, provide supplies, lastly to pay faculty salaries with much more ease than the Church-supported College of Liberal Arts. White missionaries and government programs supported Industrial education for Blacks much more than the Classical programs. The differences in the opposing programs had its implications. As Timothy Dortch points out, "The differences between the College of Liberal Arts and the Combined Normal and Industrial School, coupled with overlapping courses and unclear philosophies, served to impede any movement towards an integrated curriculum." 113 Despite the differences, Wright wanted Wilberforce University to receive accreditation so that its pupils could transfer their credit hours to other universities, therefore, the fragile compromise between the Church governed board and the state board was maintained. Though to no avail. In 1935 under Wright's leadership, Wilberforce University applied for accreditation with the North Central Association of Colleges and Secondary Schools. ${ }^{114}$ The boards' inability to effectively harmonize the courses offered is what caused the university to be denied for accreditation on its initial request. On the flipside, by the end of Wright's first presidency, Wilberforce managed to open itself to all state

\footnotetext{
113 ibid, 38

114 ibid, 51
} 
students. Explicitly stated in Section 1 of the Report of the Committee on Curriculum from Wilberforce:

It was not until 1936 that the entire University was opened up to all State students so that each student could enter any department of the university without paying a tuition fee. Prior to this time every State student was compelled to take only the work offered in the College of Education or pay a tuition fee for entering the College of Liberal Arts. As soon as it became possible for State students to register according to their interests, a number of them took advantage of the opportunity, especially those who were interested in pre-law, pre-dental, and social administration courses. ${ }^{115}$

This evidence illustrates the preference for Du Bois' educational approach by the pupils of this time, oppose to Washington's. This could have been in part due to the Great Depression and as a result a decline in faith in industrial trades' ability to provide financial stability.

From 1937-1940, Wright relinquished his duties as Wilberforce's president. However, once he returned in 1941 as an interim president, the philosophical debate over the proper educational approach fully materialized at the university and was preventing the university from gaining accreditation from North Central. Wright did not achieve accreditation in his position, but he did guide the university through the process by reestablishing the coexisting relationship between the Church board of trustees and the state board of trustees, which had been dismantled by the previous president, President Walker.

115 Curriculum Committee, "Section 1 of the Report of the Committee on Curriculum" (Wilberforce, OH: W. U. Archives, Box W. 401, Rembert Stokes Library, Wilberforce University, 20 December 1934, typewritten), 9. 
The three figures discussed in this chapter show both how central education was to the leaders of the AMEC and how the conception of education changed over time. Education was a primary concern for each leader of the church. Richard Allen planted the seed of education; Daniel Payne watered it; and Richard Wright Jr. nourished it and planted more. Each leader contributed to the expansion of education in a meaningful way. Regardless of the perceived benefits and goals attached to education, it was still promoted.

\section{The Branches of Education}

The AMEC began its educational efforts in the North around the same time that the government program, the Freedmen's Bureau, began its educational efforts in the South. It is believed that the AMEC was influenced by the efforts of the government program. Although the initial purpose of the Freedmen's Bureau was to provide Blacks with material needs, it eventually began to focus on education. In July of 1866, under the direction of General Oliver O. Howard, the government extended the work of the Freedmen's Bureau for another two-year period and this time involved the educating of Black Americans. By January 1868, the Freedmen's Bureau had established several institutions of higher learning and schools for the training of teachers. Howard University, founded on March 2, 1867, was named after General Howard. The HBCU was originally intended to train ministers. But even in the planning stage, the scope of the school was widened to include teacher training as well. By 1870, the Freedmen's Bureau believed that it had supported the South long enough in providing education and made the 
decision that it was now left to the states and churches to provide education for the newly freed Black population.

The Freedmen's Bureau was not the only supporter of Black education. There were many denominations that took up the cause. The Congregationalist, the Methodists, and the Baptists established the nation's first private colleges for Blacks. The predominately white denominations saw a need to establish institutes that would educate their Black congregants and their efforts paralleled those of the Freedmen's Bureau. They therefore, created their very own Freedmen's Aid societies through which they would later create colleges for Blacks.

Despite the fact that there were many institutions already in place and established for the Black community by Whites, the Black churches felt inclined to establish their own institutions. The Black churches realized the importance of education and thought of it as a fertilizer for the Black community; with education the Black community would grow and prosper. A contributor to the New York City African American newspaper, The Colored American, a gentleman known as A.G.B., writes about the benefits of education.

In considering the improvement which we need, I shall confine myself to those which are strictly mental and may easily be acquired, and when acquired do necessarily influence the heart or moral character of the individual. The list of those branches which are important, is not as full as I might easily make it, and includes by no means all that I deem necessary or useful, but only a few plain, practical branches, which may be gained by almost any one who has the courage to try, and the patience to persevere. Some of the studies, then, which claim our attention, are Reading, Arithmetic, Grammar, History, Domestic Economy, Composition, the Mechanic Arts, and our Civil Rights. The work of moral 
improvement is a great work. It is a practical work; much of it is work, which we must do for ourselves - it cannot be done for us - it must be done in us. ${ }^{116}$

This quote is significant because it presents two ideas being proposed during the early 1800s. First, though there is much for Blacks to learn, it is important to focus on the immediate needs of the community. Second, the author lists branches of learning, which are beneficial to Blacks due to their ability to help Blacks effectively navigate as new citizen in the United States. He focuses on branches that are essential to their survival such as reading, math, domestic economy, and the mechanic arts. In particular, he speaks of the importance of Blacks understanding their Civil Rights and how they apply to them. This indicates self-advocacy.

Initially, when the AMEC developed interest in educating for liberation it was because of the desire to liberate spiritually. As previously discussed, education was seen as vital to spiritual growth. The AMEC believed literacy was important because it opened the door to reading the Bible and learning about God and his teachings. Living a Christlike life was believed to better the lives of the practitioners by helping them cope with the complex issues of society and eventually move beyond these complexities. It is in this way that education was viewed as vital and sacred. While Daniel Payne looked at education as a spiritual catalyst he also saw its mundane benefits. In January 1854, near the time of the Kansas Nebraska Act, which was one of the most single most significant events leading to the Civil War, Payne referred to education as more than a means of spiritual development but also as a way to elevate the Black community. He states, "We

\footnotetext{
116 This quote comes from a series of articles written by a person identified as A.G.B published in The Colored American. "Thoughts," The Colored American, July 4, 1840 and March 6, 1841.
} 
are convinced that education is the only thing calculated to elevate us as a people in this country, politically, morally, and religiously. Destitute of it, we must inevitably retrograde; with it, we may hope for success. From the present indication we are led to believe that our race shall be elevated". ${ }^{117}$ It is with this statement that education and its purposes began to shift. Payne was a fervent supporter of education and consistently insisted, through speeches and writings, that the AMEC reach new and more prominent levels in the arena of education. At times, his criticism of the Church in relation to education made him a controversial proponent of education. Although the church was actively engaged with educational efforts, he wanted the AMEC to do more. Payne is often credited with catapulting the AMEC full force into its educational endeavors. Conferences began to be held regarding education and schools. At the 1854 Baltimore Conference, AMEC officials discussed the importance of having educational institutions and focused on expanding the scope of educational efforts of the denomination. In the 1850s, the AMEC was responsible for a number of educational facilities such as libraries, temperance societies, common schools, and Sunday schools. ${ }^{118}$

The educational efforts of the AMEC can be categorized into four branches: Common schools, Sunday schools, theological centers, and higher education institutions. ${ }^{119}$ Each branch was developed for the purpose of educating Blacks. The church believed that it was important for Blacks to advocate for themselves. The leaders

\footnotetext{
117 Payne, 307-308, 406

118 ibid

${ }^{119}$ Zimmerman, Constella Hines, Contributions of the African Methodist Episcopal Church and its Leadership to Higher Education for Adult African-Americans during the Late Nineteenth Century: 1865-1890, 1998, 57
} 
of the church revered education and put much effort into it since they viewed it as a tool capable of bringing about change for the masses. This was a truth held universally throughout the denomination. The following are the initiatives that the AMEC took to advance the Black community.

\section{Common Schools}

Initially, Blacks needed rudimentary education since it wasn't provided to them when they were enslaved. Therefore, once they were able to receive an education they needed support in achieving the basic levels of knowledge. Common schools were meant to accommodate the newly Freedmen that never received a formal education. The schools were to equip African Americans with the basic literacy and computational skills needed to manage their own affairs. Church leaders felt that it was no sense in wasting time in educating laypersons if they were unable to use it in their daily lives to assist them in daily matters. For example, Bishop Payne advocated for a practical education, one that had value and could be used in daily affairs. Therefore, basic training was provided in spelling, reading, writing, and arithmetic. All of these subjects were used in the daily interactions of African Americans. According to Zimmerman, both primary and secondary schools were established in the South after emancipation since it was there they were most needed. ${ }^{120}$ It is because of these schools that they were able to apply arithmetic to daily activities. This was an important skill for the newly freed slaves since they now had to make transactions when doing business with other individuals. Their

120 ibid, 66 
labor was no longer free and thus having a basic knowledge of computations would be vital. They were being provided with the necessary skill set to be free and equal citizens in American society.

\section{Sunday Schools}

For AMEC leaders and members, religion was not compartmentalized. It was all encompassing and occupied every space, including education. Religious education was not viewed as separate from basic education. Zimmerman states, "Religious education was not something added nor taken apart from education. Religion was part of education". ${ }^{121}$ This is important to state because the members of the church held religion dear since it provided the congregation with morals. Blacks had to develop habits and ways of living in this peculiar place where they were forced to live restricted lives. Church leaders were consumed with the goal of erasing the stigma placed on Blacks by their oppressors. Improving morality was just one avenue for achieving this goal.

Children and adults were both trained in these schools. Students were grouped by ages, resembling that of a typical schoolroom. In order to remedy the problems plaguing society it was imperative to target both the youth and adults. Targeting adults would create better examples for children of who would soon become citizens of the society. They served, as a sort of blueprint for what properly functioning adults ought to behave like in society. Targeting the youth would ensure a better future equipped with religiously devoted and educated Blacks. According to the 1888 Sunday school records of the 1892

${ }^{121}$ ibid, 68 
General Conference minutes, the schools were well attended. There were 3,544 Sunday

Schools, and there were 16,036 officials and teachers that operated them.

\section{Theological Centers}

Although church leaders believed that it was important to educate their

congregations, they also felt it was mandatory to educate their religious leaders. Religious

leaders were the individuals that would have the greatest impact on the people and therefore it was imperative that they were equipped with an education in order to lift them intellectually, spiritually, and socially. Prior to the Civil War, the AMEC played a dominant role in educating its people in the North; however, after the Civil War the church began to infiltrate the South and West and its role in the lives of Blacks began to increase even more. There was a call for educated missionaries and preachers. Blacks in these regions had been deprived of authentic Christianity, one that was intentional in its religious teaching. They had also been deprived of ministers that were willing to offer them resources for the betterment of Blacks and their descendants. In the northern and Midwestern states, the AMEC was broadening its focus and seeking ways to elevate the community and to dismantle the grip of economic and social oppression through education. In 1856, the AMEC founded the United States' second Historically Black College (HBCU), located in the Midwestern state of Ohio. It should also be noted that the first $\mathrm{HBCU}$, was founded in the north. Wilberforce University offered Blacks many opportunities, such as a classical education and teacher training, that southern Blacks did not have. The founding of a college for Blacks did not occur in the southern states until nine years later in Raleigh, North Carolina. So once African Americans saw these opportunities now becoming available in the AMEC they desired to be a part of them. 
The leaders of the AMEC recognized this desire and therefore sought out gentlemen that were educated, shared a personal relationship with God, and had the ability to convey this intellect intelligently to the congregation.

Ministers needed to have an education so that they could mobilize the Black community. Whether this mobilization was geared towards morality or socioeconomic betterment, each minister used education in order to actualize a dream. For example, without the ability to read, ministers lacked the ability to interpret scriptures. Without being able to interpret the scriptures for themselves their Christian duty would have been left under the care of another individual. If this autonomy were taken away from ministers, the leaders of the Black community, then they would have opted out of the responsibility of performing important duties like conveying the true and unblemished message of Jesus Christ. Moreover, AMEC ministers needed to be well educated because they were given the charge of establishing schools for African Americans. In the early nineteenth century, the Philadelphia Conference affirmed that, "It shall be the duty of every minster who has charge of a circuit or station, to use every effort to establish schools wherever convenient and to insist upon parents of children sending them to school". ${ }^{122}$ If ministers were tasked with the duty of establishing schools, then they at the very least had to have a basic level of education to provide proper learning. These are a couple of the many tasks that AMEC ministers were responsible for. They made the choice not to opt out of these responsibilities. They chose education. According to Zimmerman, "regular seminary courses were developed at Payne Theological Seminary

${ }^{122}$ Payne, The History of the A.M.E. Church, 98. 
in Wilberforce, Ohio and Morris Brown College in Atlanta, Georgia". ${ }^{123}$ In addition, efforts were made in Columbia, South Carolina, for the purpose of planning a curriculum for ministers. ${ }^{124}$ The curriculum included the study of the Bible, Christian theology, the AMEC discipline, Ancient History, and History of Christian Religions. This comprehensive education would create strong leaders, without whom, it would be difficult, if not impossible, to elevate the community.

\section{Higher Education}

Gradually, the Church's support of education expanded to include higher education in general. Though the conversation regarded only the religious leaders, the seed for higher education was planted as early as 1843 when AMEC leaders first discussed it. During the Baltimore Conference of 1843, the AMEC leaders distinctly voiced their opinions regarding education. On the May $1^{\text {st }}$, the following resolution was adopted, "That we recommend to all our elders and deacons, licensed preachers and exhorters, the diligent and indefatigable study of the following branches of useful knowledge: English grammar, geography, arithmetic, history, modern history, ecclesiastical history..." ${ }^{125}$. The branches expounded upon in the conference of 1843 are considered a classical education. Later the same year, the Philadelphia Annual

\footnotetext{
${ }^{123}$ Zimmerman, Constella Hines, Contributions of the African Methodist Episcopal Church and its Leadership to Higher Education for Adult African-Americans during the Late Nineteenth Century: 1865-1890, 1998, 69

124 ibid

125 Payne, History of the AMEC, 395
} 
Conference expanded the resolutions of the previous conference. One of the deliberations at the Philadelphia conference that is acute to the one previously mentioned is, "The light of science and literature is pervading every department of society, and the rising generation will be prepared to enter upon the stage of action with advantages far beyond what we have ever enjoyed; and moreover". ${ }^{126}$ What's noteworthy about this statement is the realization that education is pervasive. But even more substantial is the notion of activism associated with education. Eleven years later, in 1864, interest in higher education was documented in the resolutions of the Philadelphia General Conference.

Resolved. $1^{\text {st }}$ That education is of great importance, both to the colored and white races in the free states, that all the colored people should receive at least a good, common school education; and that for this purpose well qualified teachers are indispensable.

Resolved. $2^{\text {nd }}$ That the religious instruction of the colored people is necessary to their elevation as well as their salvation.

Resolved. $3^{\text {rd }}$ That we recommend that the establishment of a literary institution of a high order for education of the colored people generally, and for the purpose for preparing teachers of all grades to labor in the work of educating the colored people in our country and elsewhere. ${ }^{127}$

The first resolution is important because it shows the denomination's realization that education is equally important for Black Americans as for Whites. It also shows the need for qualified teachers to do the work. This focus on common school education, oppose to Sunday school biblical education, illuminates a shift in focus from predominately biblical gospel to social gospel. The AMEC leaders desired to elevate their

126 ibid

${ }^{127}$ The Philadelphia 1864 General Conference p. 113 
community by advocating for all Blacks to have at least a basic elementary education, which is referenced by their usage of the term 'common schools'. Prior to the $18^{\text {th }}$ century, common schools were not yet conceptualized. Education was something that was learned by daily interactions with the family and church. In the nineteenth century, the Common Schools Movement took hold. Common schools refer to the long effort of the United States to establish a system of publicly supported elementary and secondary schools. By the time of the Civil War, in most of the northern and Midwestern states common schools were present. However, in the southern and far western states, expansion of common schools progressed at a much slower rate. By the opening years of the twentieth century, publicly supported schools were common and widespread in the United States. In the $19^{\text {th }}$ century, the century in which the Philadelphia General Conference convened, common schools were present in most of the southern and Midwestern states, but not all. Moreover, in the southern and far western states, they were just beginning to appear. The first resolution expresses the AMEC leaders' desire to expand the breadth of common school in all parts of the United States and truly make common schools a cornerstone of American society. The second resolution is the most important since it clearly declares the denomination's aspiration to elevate the Black community through education. It illustrates their faith in education as being able to deliver Blacks from socio-economic oppression and offer them salvation. Moreover, the second resolution is astounding because it uses the terms elevation and salvation. Elevation refers to the Black's socio-economic wellness and salvation indicates their spiritual health. Once again, the AMEC's tendency to promote both spiritual and secular wellness is demonstrated. Finally, the third resolution shows that the AMEC was 
prepared to intervene socially on behalf of the African American community in a practical way.

The AMEC clearly was using education as its guide through and out of the hardships of its time. Higher education was imperative because it ensured that Blacks would be provided with well-equipped teachers that were prepared to take charge and guide the future generations into a better socio-economic situation. They did not simply seek immediate relief but long-term relief as well. Though the church emphasized education that would give the Black population tools to help them immediately they also understood that there needed to be a focus on a type of education that prepared their students for careers beyond fieldwork and factory jobs. The AMEC's approach to education was different from institutions that relied on the methods such as the HamptonTuskegee model to educate its students. The AMEC placed its emphasis on graduates being prepared for educational, political, and social leadership. This is not to say that they did not teach vocational classes or see an importance in doing so but simply that it was not the sole or primary emphasis. Other scholars have noticed how the AMEC differs from other Black Churches in its focus as well. Zimmerman states, "The educational approach of the AMEC differed from the educational program at most industrial schools, such as Tuskegee Institute, in both content and emphases. AMEC colleges emphasized classical and liberal arts courses, and the industrial curriculum took a secondary role". ${ }^{128}$ In addition to these courses, the AMEC colleges also emphasized technical training and technology to prepare Blacks to become engineers, architects, and industrial managers. Overall, the church was concerned with preparing Blacks for careers not jobs. A career is

${ }^{128}$ Zimmerman, 77 
done out of passion and desire; a job is done to generate revenue. Offering Blacks a variety of choices, from a career in industrial work to education, gave them permission to decide what career they wanted to pursue, while still allowing them to be financially secured. They did not want the Black community to 'get by' or barely make 'ends meet'. Their goal was to enrich the Black community and to provide them with the skills and resources to succeed in the game of life.

In order to provide the community with this skill set the AMEC had to rely largely upon its leaders and members for financial support. The church was making every effort to supply its community with adequate education. Constella Zimmerman writes, “ In 1885 , the AMEC raised in excess of $\$ 11,000$ for educational purposes. And according to the "Report of the Committee on Education" at the 1888 General Conference, more than $\$ 500,000$ was raised for the Church's education institutions between the years of 1884-1886" ${ }^{129}$ The money raised during this time period was used to support the schools and colleges owned and operated by the church. Bishop Embry, in 1890, stated, "The Church's educational department, which had been established in 1886, forged ahead with the mission to increase the facilities for education among us, and to bring those facilities within the reach of the masses of our people". ${ }^{130}$ From the funds raised, the church founded eight colleges in the southern states: Arkansas, Florida, Georgia, Mississippi, North Carolina, South Carolina, Tennessee, and Texas. Additionally, the church also supported other educational institutions such as Turner Normal School in Tennessee; Campbell College in Mississippi, Edward Waters and Flipper Key Davis Colleges in

${ }^{129}$ Report of the Committee on Education, 246 qtd in Zimmerman, 78

${ }^{130}$ Zimmerman, 64 
Florida; and Central Park Normal and Industrial School, Payne Institute, and Morris Brown University in Georgia. Finally, the AMEC also had Western Universities in Kansas and Wilberforce University in Ohio. The above-mentioned colleges and universities were what comprised the AMEC's higher education institutions.

As previously stated, the church had raised most of its money for its educational initiatives on its own. However, it did receive outside assistance as well. The AMEC received support from the John F. Slater Fund. The Slater Fund was established in order to help support Black institutions of higher education in providing industrial education to African Americans. Established in 1881, the Fund supported many Black institutions in the late nineteenth century. By the time the fund ceased in 1937, it had given approximately 4,000,000 for the purposes of educating newly Freedmen. It must be noted that moneys were given to institutions that only provided industrial training to their students. Since the AMEC focused primarily on liberal education, giving industrial education a secondary focus, only one of its institutes received funding and that was Paul Quinn College in Texas during the years of 1887-91. It received a total of \$600. John F. Slater was not the only northern philanthropist that solely supported industrial education. In fact, the majority of northern philanthropists used their money in order to support vocational training, withholding their financial support from those that did not, like the AMEC.

\section{Hampton-Tuskegee Model versus Liberal Education}

After the Civil War, the majority of African Americans were illiterate, poverty stricken, and socially unorganized. Though the North had won the Civil War and Blacks 
were emancipated, many white southerners still considered Blacks to be the lowest caste, a slave-caste. Therefore, conversations about educating Blacks were viewed as impossible and ridiculous. White southerners believed Blacks did not have the intellectual capacity to attain an education equivalent to that of Whites. Several highly controversial issues regarding the philosophy, methods, and content of Black education emerged. From this controversy emerged the Hampton-Tuskegee Model. The HamptonTuskegee model was a mixture of Samuel Armstrong and Booker T. Washington's educational philosophies. Born on January 30, 1839, Armstrong was the son of missionaries. ${ }^{131}$ Armstrong received his elementary education in Hawaii, but after his father's death, moved to the United States to attend college. Afterward, he served in the Union Army during the Civil War. ${ }^{132} \mathrm{He}$ rose through the ranks and became the lieutenant colonel; he was assigned to the $9^{\text {th }}$ Regiment, United States Colored Troops in late 1863. It is in this position that he gained concern for the welfare of African Americans. He continued to be a vital asset to the Union for the duration of the Civil War. After which, he joined the Freedmen's Bureau and with the help of the American Missionary Association established Hampton Institute. The American Missionary Association (AMA), officially established in 1846, consisted of three missionary antislavery societies. After 1850, instead of focusing on establishing missions for freed slaves overseas, the Association focused its attention upon abolitionist activities. Once the Union armies began freeing slaves during the Civil War, the Association opened

\footnotetext{
131 "Related Information." Samuel Chapman Armstrong. Accessed March 16, 2019. http://www.hamptonu.edu/about/armstrong.cfm.
}

132 ibid. 
schools. The AMA established more than 500 schools for freed slaves in the South in the years following the war. Eventually, the South recovered from the economic downturn of the war and developed public school systems. This served as a catalyst for the AMA, and prompted them to sign over its elementary and secondary schools in order to focus on improving and expanding colleges for African Americans in the South. The AMA founded nine predominately Black Colleges, of which Hampton institute was one. Armstrong's Hawaiian's Hilo Boarding and Manual Labor School inspired his college model. The model provided an academic curriculum but mostly focused on training teachers and manual labor as a device for building character. Students were able to receive a post-secondary education to become teachers, in addition to receiving training in useful job skills. At the Hampton Institute, there were several shops geared towards building character through manual labor: sawmill, soap-making shop, a broom making shop, a grist mill, a carpet making shop, and clothing manufacturing shops. Stephen White claims that the model "gave the students their required manual labor experience; provided them the opportunity to earn part or all of their school expenses; and served as training media for certain occupational skills". ${ }^{133}$ It is in this way that Armstrong created opportunities for blacks to afford an education and gain skills that were to be immediately useful upon graduation. After mentioning his intentions in providing a technical education, a one thousand dollar endowment from the Slater Fund was provided to Armstrong's school making it possible for him to open a shop for technical training in the

${ }^{133}$ White, 337 
use of carpenter's tools. ${ }^{134}$ Booker T. Washington, an ex-slave that graduated from Hampton Institute went on to adopt and adapt the Hampton model when he became the first principal of Tuskegee College in 1881. He developed the industrial aspects of the curriculum much faster than Armstrong did. On Tuskegee's $25^{\text {th }}$ anniversary, Washington had provided the Black community with a 2,000-acre, three building campus; the institute was valued at $\$ 831,895$ with an endowment fund of $\$ 1,275,644 .{ }^{135}$ Under Washington's leadership, the college provided training in thirty-seven industries. ${ }^{136}$ After Washington's enhancement of the model, it came to be known as the Hampton-Tuskegee model. This was due to the funds that he was able to amass from wealthy White northern donors. Some of individuals were John D. Rockefeller, Jr., Anna T. Jeanes, and Julius Rosenwald. Hampton and Tuskegee would later develop into colleges that focused primarily on vocational training.

The early Hampton-Tuskegee program desired to provide the newly Freedmen with a skill set that would be immediately beneficial to their current socio-economic position. This is the reason why it focused on blue-collar work. Booker T. Washington's principles starkly contrasted with those of the AMEC leaders. Washington favored vocational education above liberal education. Vocational education did not threaten whites and in many ways supported and reinforced the stereotype that Blacks were only suited for limited careers. These careers often included agriculture, carpentry, masonry,

\section{4 ibid}

135 "Dr. Booker Taliaferro Washington." Tuskegee University.

136 ibid 
and homemaking. ${ }^{137}$ In addition to disagreeing with Washington's principles regarding education, AMEC leaders also disagreed with his political views. He is said to have valued teachers that taught Blacks to avoid politics and accept their position in society as semi-skilled workers. ${ }^{138}$ Moreover, he didn't believe in Blacks pursuing equality but instead encouraged them to acquire craft skills and work industrially. Simply put, the Hampton-Tuskegee model essentially reinforced Black subordinate position in society by encouraging them to continue to do the work that they did when they were slaves. To clarify, the AMEC did not oppose honest labor, but opposed the commonly held belief that manual labor was the only jobs Blacks were capable of doing. African Americans had the same intellectual capacity as their white counterparts and should have the choice to pursue any educational program they so desired. Due to these reasons, the AMEC opposed this model and did not receive financial support from northern philanthropic organizations, wealthy southerners, or the federal government. Consequently, the church did not have support in paying their teachers' salaries or with purchasing equipment. This is significant because it illustrates the church's capacity for self-advocacy no matter the barriers formed against them. The AMEC refused to follow the Hampton-Tuskegee model because it did not align with its future goals and aspirations for the Black community. The goal was to mobilize the Black community so that it could gain liberation and be self-sufficient. The Hampton-Tuskegee model directly contrasted with this goal and in fact stifled Blacks' drive towards socio-economic freedom. Instead of following the model advocated by Washington, Northern religious bodies, wealthy white

\footnotetext{
137 Zimmerman, 91
}

138 ibid 
southerners, and the government, the AMEC opposed it and sought out to provide its members with a broader, liberal education without the assistance of individuals that did not support its values and goals. It turned out that they were better off without the support. According to Constella Zimmerman, "The AMEC provided more financial support for their institutions than did the white denominations that had established schools for the purpose of Black higher education". ${ }^{139}$ In 1878, Bishop Arnett also observed, " The black denominations have rendered splendid service to the education of the race and, in comparison with other colleges for Negroes supported by white denominational boards, the Black colleges have been well supported by their own". ${ }^{40}$ For many AMEC leaders, Booker T. Washington's educational ideologies placed Blacks on a path of stagnation without any hope of altering their position in society. In 1895, the AMEC Recorder responded to Washington's educational philosophy as "essentially a blueprint for Black subordination". ${ }^{141}$ This statement makes it clear that the church had no intentions of straying away from the goal that they set for their community. If the government or anyone else were not willing to support their educational aspirations unless they conformed to the Hampton-Tuskegee model then they would make do with what they had. It proved to be successful. The 1888 Annual Conference Committee minutes reflects on its success:

\footnotetext{
139 ibid, 89

140 ibid, 57

141 ibid, 82
} 
We are now; say Dr. W.D. Johnson and Bishop B.W. Arnett, in possession of 17 schools, 58 professors, 1539 students, [and] 157 graduates. Collected for educational purposes: $\$ 123,950.00$. Value of each property; $\$ 305,950.00$. Amount of school debts, only $\$ 28,871.81$. These figures were submitted to our most recent general conference and speak for themselves to the credit of our worthy leaders and advancing church. ${ }^{142}$

The lack of support from the government or other capable parties did not affect the educational programs offered by the church to its members. Money had a direct impact on whether or not the AMEC leaders were able to provide their members with an education that they felt was worthy of them. Money was not a problem since they did what was necessary collectively to bring to fruition their goals. Church leaders were not ignorant and realized that manual labor and industrial training had benefits, but they also realized that the benefits of these two types of training were limited when they were the only type of education acquired by the Black community. African Americans required a comprehensive education to be a stable community. The AMEC leaders looked at education differently from many other denominations and leaders. They saw it as the most important device capable of altering the position of African Americans in American society. Education had to provide Blacks with the means to integrate into American society; it had to allow Blacks entrance into the social, economic, and political life of America. The historical AMEC understood this philosophy and advocated it.

1421888 Annual Conference Committee minutes p. 205. 


\section{THE CONTEMPORARY A.M.E. CHURCH AND SOCIO-ECONOMIC BETTERMENT}

\section{Modern Initiatives}

Integrating African Americans into every aspect of American society is still an aspiration of the AMEC. The historical emphasis placed on education and economic uplift through self-help, continues to be promoted in modern times to develop the socioeconomic position of Black Americans. Dr. Floyd Flake, a minister and congressman, suggests that America has a third world within itself — it's African American communities. ${ }^{143}$ If this is true, then the AMEC is currently working to dismantle America's system of inequality by creating a strategic plan to improve the lives of its members. Though diligently advocating for equality and developing various initiatives, the church hopes to change the experiences of many African Americans that are still very similar to those of their ancestors.

An executive summary of this plan was published on their official website. According to this document, in September of 2002, the AMEC endeavored not only to continue but also to reenergize and reform the historical objectives of the church. In order to do this effectively, the AMEC had "Success Results Consulting, Inc. (SRC), an organization development firm located in Germantown, Maryland, facilitate this process using a research based, five-phase strategic planning process. The 90-member Strategic Planning Core Team (SPCT) consisted of a microcosm of the AMEC membership and included Bishops, General Officers, Presiding Elders, Elders, Pastors, Lay Persons, and

${ }^{143}$ Flake, 1 
Youth. ${ }^{144}$ This inclusive group conducted two surveys of the Church membership. According to the document, two surveys were required. One survey was needed in order to give voice to the general public regarding the various capacities in the AMEC. The official AMEC document states, "The first survey, from which 10,500 responses were collected, was intended to give the populace an opportunity to voice their honest opinions of the existing strengths, weaknesses, opportunities, and threats (SWOT) in the AMEC". ${ }^{145}$ The second survey, consisting of 15,058 responses, was more focused and only involved the Church's membership; it is said to have provided more detailed information in regards to demographics and personal sentiments as members of the AMEC. These two surveys led to a list of topics that are pertinent to the AMEC's success in the $21^{\text {st }}$ century.

While there were several different topics listed in each category of the AMEC's SWOT, I will only list the topics in each category that are relevant to this research topic. In the category of strength, three topics that are noteworthy to my current research are: educational institutions, leadership community outreach, and real property ownership. In the areas of weaknesses one particular topic stood out as extremely important — lack of finance and economic development. The AMEC's opportunity category has four significant topics: training/education; outreach ministries; finance; and youth economic development. Lastly, the category of threats has two topics worth mentioning and they are lack of finance/accountability and leadership education.

\footnotetext{
${ }^{144}$ AME Church. "Strategic Plan." AME Church. 2002. Accessed April 01, 2019. https://www.ame-church.com/news/strategic-plan/.

145 ibid
} 
In the category of strength, AMEC's listed strengths are definitely justified, especially considering the Church's history and its involvement in social reform activities of this sort. AMEC's educational institutions were listed as one of its strengths. AMEC's advocacy for Black education and its involvement in bringing that education to fruition has constantly been demonstrated throughout its history and documented in this research. The fact that the institution realizes its stupendous contribution to this area is promising because it still sees it as an area of importance, important enough to list as one of the many areas that it is most strong in. Though listed as strength, data from the surveys concludes that education was an area of possible growth and one where it can continue to thrive and develop. Possibly, this is why it was also listed under the category of opportunities. There's always room for improvement. In the AMEC's Strategic Planning Implementation Handbook, a handbook that outlines proposals and an implementation plan for each area of concern within the church, education is addressed as "Strategic Thrust \#7: Improve Education, Growth, and Development". ${ }^{146}$ Seven recommendations are given that are meant to provide AMEC's religious leaders with a concrete plan. The recommendations listed in the document are: That the General Conference establishes a department of Higher Education. The General Board hires an Executive Director with adequate staff and necessary resources; Provide proper training for Board Members of Higher Education Institutions to ensure training in accordance with applicable law and accreditation requirements; Provide training for person in leadership capacity in the local congregation, Presiding Elder District, Annual Conference, Episcopal District, and Connectional Church; Increase funding for the AME Institutions of Higher Education;

146 ibid 
Develop comprehensive and competitive written resources; Create an Editorial Board that annually reviews publications of the AMEC and makes recommendations for the improvement of the quality of the material; and certify all AME teachers. With each recommendation, the AMEC considers the existing process; process for implementation; the individuals that need to be involved; and a strategy to execute the plan. ${ }^{147}$ The first recommendation, regarding the establishment of an AMEC Department of Higher Education and having an Executive Director to lead the department demonstrates the $21^{\text {st }}$ century AMEC's ambitions concerning education. Higher Education institutions, such as Wilberforce University and others, would prosper more if there were one department uniting all of the universities and colleges. In the past, no such department was spoken of as a priority and it therefore did not exist. However, now in the $21^{\text {st }}$ century with the increasing amount of African Americans aspiring to earn a college degree, it is necessary. The establishment of the department and assigning an individual to coordinate it is indispensable. According to the handbook, the Executive Director of Higher Education would be responsible for coordinating and planning all issues concerning accreditation, funding, development of standards, assist institutions with Policy Development regarding educational systems of higher education, interpretation of the standards of the accrediting agencies, and provide continuity of denominational standards among the educational institutions. ${ }^{148}$ The establishment of this department and director is quite purposeful and would prove itself as an asset to the AMEC's educational aspirations. It would also prove

\footnotetext{
147 ibid
}

148 ibid 
to be useful for the African Americans attending these institutions. With the development of this department, three improvements can be made. First, it has the ability to improve the quality of education of AMEC schools. Additionally, it can assist schools in building development capacity. Furthermore, it also has the ability to assist with institutional effectiveness.

The second recommendation is just as important as the first one; the second recommendation seeks to provide proper training for Board Members of higher education institutions to ensure training in accordance with applicable law and accreditation requirements. The leadership of any organization must be properly educated and informed, lest they lead ineffectively and educate unsuccessfully. Ensuring that the Board Members of the higher education institutions are properly trained increases the likelihood of its graduates' success. Currently, the AMEC does not have an existing process for this training but the idea of implementing one is the first step towards progression and effectively targets one of their threats, which is the lack of educated leadership. The AMEC plans to train the leaders of its universities and colleges "through seminars, retreats and workshops". ${ }^{149}$

The third recommendation already has an exiting process relating to training persons in the leadership capacity. While this education does not directly affect the masses and the academic education of African Americans, it does affect the knowledge of the leaders that lead the congregation, which is equally important. This recommendation assists with addressing both a strong suit of the church and one of its areas of needed development.

149 ibid 
The fourth recommendation is extremely significant, and unlike the third, directly affects African Americans educational attainment. AMEC recommends that the funding for its institutions of higher education be increased. Increasing the funding for these institutions increases its ability to compete with other universities and colleges. The steps being taken to fulfill this proposal are establishing an AMEC educational endowment, seeking grants, and government grants for the AMEC's institutions. It is unclear whether or not the AMEC higher education institutions are currently being provided with government assistance, but if they aren't, the AMEC are currently seeking its help.

The fifth and sixth recommendations propose that the AMEC develop more comprehensive and competitive written resources; additionally, the creation of an editorial board to review these publications is also proposed. These are critical and really underscore the AMEC's tendency to socially intervene and advocate on behalf of its community. Publishing comprehensive work illuminates issues that the Church, Black community, and nation are all experiencing. Knowing ones predicament and understanding what is going on around one is key to changing, sustaining, or improving a situation. Having well written work and a board to review it ensures that the Black community knows what's occurring in their immediate community and the world at large. It also is a media source for individuals outside of the AMEC to learn about its many accomplishments.

The seventh proposal, certification of all AMEC teachers, directly aligns with the AMEC's aspiration to mobilize the Black community. Education is viewed as critical and inseparable from Black success. This includes both academic and Christian education. This has always been a realization and truth for the AMEC. This explains why there 
currently is an existing process for the AMEC teachers to gain certification. The process involves the Department of Christian Education — and based on the information provided by the AMEC it "certifies Sunday School Superintendents, teachers and Christian educators. Training occurs at regularly scheduled events of the church (i.e., District Conferences, Mid-year Convocations, etc.)" ${ }^{150}$ But in order to increase the amount of AMEC educators and to ensure the accreditation of the existing teachers, the institution is implementing additional strategies to strengthen this area. Publishing certification classes in the AMEC Magazine, journals, and papers increases the likelihood of prospective students knowing when there is an opportunity to earn their educator certification. Moreover, supplementary information is also being published in all current publications of the AMEC. These marketing strategies on behalf of the Department of Christian Education promote its education program to its own congregation as well as other members in the Episcopal district. The most forward thinking strategy of all is the development of an online Christian Education certification program. We now live in a time where students are able to earn various types of degrees from the comfort of their home. This may be very useful for individuals that are currently working full time and find it difficult to make it to an in-person class. It is also beneficial for single parents that do not have additional support at home. No matter the scenario, providing individuals with multiple opportunities to earn certification is imperative. Similar to numerous other institutions, the AMEC has realized the necessity of educating online. The AMEC's continuous social involvement and creation of innovative programs and opportunities to

\footnotetext{
${ }^{150}$ African Methodist Episcopal Church, Strategic Planning Implementation Handbook, 58
} 
provide Blacks, both ordained and nonordained, with the necessary tools to better their socioeconomic position in society proves that it's as active and relevant as its past self.

Outreach programs are important because they ensure that the community in which a church resides is receiving services that they might not otherwise have access to. Services provided in the programs range from assisting members with prescription copays to providing care packages to first AMEC college students. Leadership community outreach, listed as an AMEC strength and opportunity for further growth, allows the leaders of AMEC to help revitalize America's third world country - its Black communities. Historically, the Black Church and its members have always worked collectively and as a unit to support Blacks. This is still a motive for AMEC in the $21^{\text {st }}$ century and so is financial freedom.

Owning property is central when attempting to gain wealth. Therefore, the fact that owning property is considered a strength of the AMEC is no surprise. In the $21^{\text {st }}$ century less than half of African Americans own property. Owning property can be viewed as a stepping stone for the Black community because historically the Black Church has been the only institution concerned and vigorously engaged with the Black dilemma and actively searching for ways to dismantle it. This dilemma has always concerned Blacks' second-class citizenship and the denial of their rights in all aspects of life including education but also economic. The AMEC's ownership of property gives it a type of knowledge that many African Americans do not have. Therefore, it is better equipped to help its immediate community in regards to finances and property ownership. While classified as both a strength and opportunity — it also was considered an area of weakness and a threat to the institution. The survey results are contradicting being that 
finances were recorded as an opportunity but also a weakness and a threat. Lack of finance and economic development is very concerning and can prove to be detrimental if the institution does not stabilize this field. In order to target this category, it has been included as a strategic thrust plan in the AMEC's strategic planning implementation handbook. It also has several recommendations and plans. It is evident that the AMEC is taking practical measures to target areas of concern regarding the financial success of the Black community and its leaders.

Throughout history, the AMEC has demonstrated its unwavering devotion to its community. Historically, education was held in a high esteem because of its ability to bring economic stability to fruition. Recently Freedmen did not have access to a formal education nor did they have the necessary skills to effectively participate as citizens in their new country. The required skillset was not afforded to them because their existence in the country initially did not require it. For newly freed slaves and their descendants, their love for education was linked to the believed subsequent enrichments it would bring. Education was the first step in the long journey towards socio-economic equality in America. Whether the education acquired was one of liberal arts or an industrial one, Blacks hoped to learn something that would be of help to their at the time oppressed and poverty stricken community. Education provided them with a necessary skill set to obtain economic freedom. With this freedom, it was hoped that they would be able to venture into mainstream society and enjoy the fruits of their labor. This hope included a continuation of money flow, and the subsequent benefits of being financially well off. In the past, education was not as accessible as it is today, but it gave Blacks the tools to alter their position in society. According to a study completed by the Pew Research Center in 
2017, growing shares of Blacks are completing high school and college. However, the research also states that despite the growing number of Blacks completing high school and college there is still a large gap between Blacks and whites on measures of wealth and income. Unfortunately, this is an unjust but consistent pattern in American history. In the $19^{\text {th }}$ century, $60 \%$ of Black men, despite their acquired education were subjected to working the lowest paying jobs either domestic or low skilled work. Apparently, in today's time, this pattern continues and there remains no direct correlation between education and economic stability.

Despite African Americans becoming more and more educated in schools and universities, they still earn only $\$ 11,200$ per household compared to $\$ 144,200$ of their white counterparts. Today, most African Americans look at education as a pathway to live a fulfilling life doing what they love while simultaneously making a living for themselves. In modern times, African Americans still perceive education as a tool to assist in the betterment of their lives. For example, obtaining an education is seen as an accomplishment but also a chance at home ownership and in general the ability to be financially affluent. Today, the AMEC is still striving to achieve salvation on earth and in heaven. Though there is a difference. Richard Allen thought of education in the context of religious salvation. He viewed it as necessary because in order to be a devout Christian one must be well versed with the Bible. For Richard Allen, reading was a prerequisite to being a Christian because the only way to ensure that one was not being misguided and was properly adhering to the Lord's commandments was to read and understand the mandates for oneself. Biblical knowledge was to be applied to the secular world, but Richard Allen did not provide the practical measures to do so. Daniel Payne and Richard 
Wright provided a social gospel. Education was used to read and interpret the bible, but also to aid in social elevation. In modern times, the benefits of education are thought of in the context of religious and secular salvation. The benefits resemble Richard Wright's philosophies of Christianity, education, and money. It is directly aligned with the concepts of liberation theology. The benefits of education are economic freedom and betterment. Despite the educational growth of the Black community, Daniel Payne's hope for the elevation of the Black race is still slow coming and not fully actualized. Though Blacks are continuously becoming more and more educated the financial freedom that was hoped to accompany it has yet to reveal itself. Blacks earn more money than they did in the past but there is still a large wage gap. Consequently, the AMEC, still placing great importance and focus on higher education initiatives, has had to refocus its initiatives in order to continue helping the Black community prosper. As demonstrated earlier, the AMEC still regards its higher education institutions as a central focus of its plans for the $21^{\text {st }}$ century. Nevertheless, instead of solely understanding education in terms of liberal arts and industrial, education is also regarded in terms of socio-economic elevation, as it was in its past. The church is working to educate its community in ways that'll teach it how to be prosperous in the new America.

In 2017, only forty-three percent of Blacks owned homes, according to the annual report from the Joint Center for Housing Studies of Harvard University. ${ }^{151}$ This is a small percentage compared to the seventy-two percent of Whites that own homes. This gap is large and has widened in the past three decades. As the housing market continues to

${ }^{151}$ Joint Center for Housing Studies of Harvard University. The State of the Nation's Housing 2018, 19, Annual Report 
recover from the Great Recession of 2008 nearly a decade after, little has improved for most Blacks. Although there was a recent increase in the national homeownership rate, this percentage does not include most African Americans. The gap between Black and White households remains. Compared to Asians, Hispanics, and Whites, Blacks have had the least amount of growth. Despite the financial achievements made in other areas, the American dream of owning a home still remains far out of reach for Blacks. This has a negative and potential lasting effect on future Black generations if the disparity persists. Homeownership is one of the pillars of building wealth, especially intergenerational wealth. According to an article in the Washington Post, African Americans households are worse off than they were 30 years ago. ${ }^{152}$ The article goes on to say that the little progress Blacks made regarding homeownership since the passage of the Fair Housing Act in 1968 was "wiped away by the foreclosure crisis". ${ }^{153}$ Statistically, African Americans make less than their White counterparts. But, people of color are more likely to be charged higher fees when attempting to take out a loan to buy a home. These two coupled together makes it incredibly difficult, if not impossible, to buy a home and subsequently generate intergenerational wealth. Albeit Blacks are making tremendous educational strides by successfully completing high school, college, and higher degrees, they still have yet to gain equal economic affluence.

\footnotetext{
152 Marte, Jonnelle, We Haven't Made Any Progress': Black Homeownership Is Stuck near 30-year Lows, 2018

153 ibid
} 


\section{Black Wealth 2020}

The disconnect between educational attainment and economic growth is what may have prompted the AMEC to enter into a partnership with the presidents of nineteen Black banks in the United States. According to their website, "Black Wealth 2020, a movement, aims to unite some of the most historic national economic, civic, and civil rights organizations with a goal to impact economic outcomes in Black America through the year 2020 and beyond. The group's three pronged strategy is to significantly increase the number of Black homeowners, strong Black-owned businesses, and deposits in Black banks". ${ }^{154}$ The subsequent tide of economic vitality was too slow coming despite the progress Blacks were making educationally; therefore, the AMEC entered into partnership with the organization in order to improve African Americans financial vitality. The education that the AMEC is now dedicated to is one of socio-economic value. They are educating the community on how to purchase homes and stay in them. They are also teaching the youth the value of saving and the value of investing. While significant importance is placed on obtaining a college degree, there is also great importance put on how to function in a society where a college degree does not necessarily means making more money or being financially stable. The following paragraph will examine the motives of Black Wealth 2020 and the benefits of the AMECs' involvement.

The organization is a separate entity from the AMEC; however, the partnership between the two groups seems to be full of prospects and directly aligned with the historic and now contemporary motives of the religious institution. Additionally, the

${ }^{154}$ Black Wealth 2020. 
decision to partner with Black Wealth 2020 is practical. The church is adapting to the Black community needs. In the $18^{\text {th }}$ and early $19^{\text {th }}$ century rudimentary education was the most essential need of the time for African Americans. Most of the education attained was not formal, but was taught in secret or by willing slave masters. Slavery was still widespread; consequently, there weren't many career choices for most Blacks. However, as time passed the type of education and work conducted and desired by Blacks begin to change. So did the church involvement and promotion of certain types of education and work. In the late $19^{\text {th }}$ century, Daniel Payne proposed a different type of education and work ethic. Daniel Payne lived from 1811-1893 and so many major events happened in that time period that influenced him and subsequently influenced the way in which he was involved in church affairs. He openly spoke out in favor of education. Additionally, he vocally connected education to the plight of African Americans. He also, worked to connect it practically. His founding of Wilberforce University in 1856 dramatically changed the direction of education for Blacks and the level of involvement that the church was willing to commit itself to. With not only a formal education but also one of a higher level, African Americans were paving the way for their future. The type of education offered would only fortify and diversify over time, giving Blacks more knowledge. In this same time period, work and career choices were primarily restricted to manual labor, work very similar to the type of work done during the time of slavery. But this would begin to change in the $20^{\text {th }}$ century with the support of the AMEC. Richard Wright Jr. was the $20^{\text {th }}$ century education and economics advocate for the AMEC. He promoted several educational and economic endeavors. As previously mentioned, while Wright Jr. was editor of the Christian Recorder, he also remained involved in banking 
and founded Citizens and Southern Bank. He also debated about the best educational path for African Americans. Education, he believed, should be economics' companion. Having a proper education, Wright Jr. believed, should equate to having financial freedom. Wright stands as a symbol for the AMEC's ambitions. He understood that education went beyond books and needed to be applied practically. His Black owned bank could be seen as a practical act on behalf of the AMEC leadership. It was very successful for its time and further promoted Black self-help. Most importantly, it explains why the modern AMECs would be so willing to partner with Black Wealth 2020. Banking and financial freedom was always a part of their vision of helping the Black community. Now in the $21^{\text {st }}$ century, the AMEC has found a practical measure to actualize its dreams of both an educated and financially flourishing Black community. The third prong of the Black wealth 2020's initiative focuses on Blacks depositing money into Black owned Banks, which in turn would make it more feasible for African Americans to receive loans for businesses and homes; thus generating wealth in the Black community.

The contemporary AMEC is as actively engaged in social reform as it once was historically. What is worth mentioning is the development of different types of initiatives and partnerships that the contemporary church is involved in to assist in the betterment of the community. Furthermore, what's noteworthy is the denomination's treatment of education and money. Beginning in the $19^{\text {th }}$ century, education progressively became interconnected with money. Now, in the $21^{\text {st }}$ century, the two factors are still interconnected; however, the AMEC's focus is primarily centered upon educating the Black community about economics and finances. It realizes that despite African 
American college graduation rates hitting an all-time high, economic outcome still lag behind. In 1968, the National Advisory Commission on Civil Disorders, better known as the Kerner Commission, delivered a report to President Johnson. The report was an examination of the causes for the civil unrest in Black communities after Dr. Martin Luther King, Jr.'s death. In the report, it named “white racism” leading to "pervasive discrimination in employment, education and housing" as the reason for the unrest in the African American community. ${ }^{155}$ The author of the report declared that the country commit itself to "the realization of common opportunities for all within a single society". ${ }^{156}$ That was 51 years ago. Today, African Americans are much more educated than they were in 1968, however, their financial prowess is not increasing as steadily as their educational achievements.

Today $90 \%$ of Blacks from ages 25-29 have graduated from high school. In 1968, only just over half graduated. This means that the high school graduation rate gap between Blacks and whites has nearly closed. Additionally, today African Americans are almost twice as likely to have a college degree than they were in 1968 . This would lead one to assume that the substantial growth in educational attainments would result in equally substantial progress in wages, incomes, and wealth. But this is not necessarily true. In 2019, Black workers earn 82.5 cents to every dollar earned by white workers. African Americans are also 2.5 times as likely as whites to be in poverty, and the median

${ }^{155}$ Report of the National Advisory Commission on Civil Disorder, 1968

156 ibid 
white family has 10 times as much wealth as the median Black family. ${ }^{157}$ Over the past five decades, American society has yet to improve homeownership and unemployment rates for its Black citizens. Compared to 1968, unemployment rates have grown. In 2017, the Black unemployment rate was $7.5 \%$, up from $6.7 \%$ in $1968 .{ }^{158}$ This is nearly twice the unemployment rate of whites. "The unemployment rate for whites was $3.8 \%$ in 2017 and $3.2 \%$ in $1968 \% .159$ This is troubling because though there has been significant improvement in Black education, it has not led to a decreasing of the overall unemployment gap between Blacks and whites. More importantly, it shows an unfortunate economic regularity and disparity between American citizens. The percent of African Americans owning homes has practically gone unchanged in the past 51 years. According to the article, 50 years After the Kerner Commission, "In 2015, the black homeownership rate was just over 40 percent, virtually unchanged since 1968, and trailing a full 30 points behind the white homeownership rate, which saw modest gains over the same period." 160 In 1968, 41.1\% of African Americans owned homes compared to $41.2 \%$ in 2019 . Homeownership is known to increase both family and intergenerational wealth, especially for working and middle-class families due to home equity. Another strikingly disappointing fact is the relatively slow growth in hourly

\footnotetext{
157 Jones, Janelle, John Schmitt, and Valerie Wilson, 50 Years after the Kerner Commission: African Americans Are Better off in Many Ways but Are Still Disadvantaged by Racial Inequality, 2018

158 ibid

159 Table B-43. Civilian Unemployment Rate by Demographic Characteristics, 19682009

160 ibid
} 
wages for Blacks, especially considering the large progress made regarding educational attainment. With inflation considered and adjusted, the article 50 years After the Kerner Commission reports, "Household income is examined. Between 1968 and 2016, Black household income increased by $42.8 \%$ [an increase of $14.2 \%$ ], which is more than White American households (36.7\%) in the same time period. Though the household income for Blacks has increased remarkably, they still earn only $61.6 \%$ of the annual income received by the average white household". ${ }^{161}$ This data proves that, despite the substantial progress made in regards to educational attainments by Blacks, they are still disadvantaged in many important ways as a race and relative to whites. Blacks are still confronted with many of the same economic and social inequities in 2019 as they were in 1968. There is still pervasive discrimination. The primary concern of the African American churches when they were founded was to create a gospel free of racial discrimination, one that could advance the Black community. It hoped for and sought after freedom. Freedom extended beyond the biblical and spiritual realm and penetrated the secular world as well. Historically, education was seen as the tool capable of bringing about social and economic freedom. However, as evidenced by the presented data these hopes have not been fully realized. The AMEC realizes this. Therefore, there has been a shift of focus from formal education to social and economic education in order to assist the Black community in confronting this long lasting and unfortunate problem. Black Wealth 2020, an economic organization with the desire to unite historic national economic, civic, and civil rights organizations in order to strengthen the economic

${ }^{161}$ US Census Bureau. "Data." Census Bureau Quick Facts, 2018 
position of Blacks in America, is a practical example of how the AMEC is switching from a focus on a formal industrial and liberal arts education to a socio-economic education. African Americans are increasingly achieving new levels of education; the partnership between Black Wealth 2020 and the AMEC is able to provide the Black community with knowledge in regards to increasing the wealth in the Black community, thus strengthening their social and economic position in America. The partnership between the AMEC and the organization allows for a transfer of knowledge that will prove to be beneficial to the Black community. Black Wealth 2020 provides information on topics such as economic justice, access to capital, the benefits of Black-owned financial institutions, how to achieve and maintain a great credit score, repayment of student loans, and saving to the AMEC religious leaders in order to be imparted to the Black community. All of these topics are crucial to a social and economic education for the Black community. Partnering with Black Wealth 2020 is one of the most practical steps taken by the religious institution.

The partnership between the AMEC and Black Wealth 2020 demonstrates the denomination's ability to recognize its community's current struggles and its willingness to adapt accordingly. Religious leaders have realized that their congregations are becoming more and more formally educated. In the AMEC, there are only $7 \%$ of congregants that have less than a high school degree. $28 \%$ of the members have a high school diploma; $44 \%$ have completed college coursework; and $21 \%$ have earned college degrees. Therefore, based on these percentages it can be concluded that earning a high school or college education is no longer a battle for the Black community. The majority of Blacks in this denomination has at the very least an adequate education. Unfortunately, 
the usual equation of greater educational attainment equaling greater economic success is not quite adding up. Consequently, the AMEC is currently taking steps to correct this error. In 1968, the Kerner Commission report discovered specific economic and social inequities confronting African Americans. The economic problems of 1968 are still confronting the Black community. Since then, the AMEC has consistently pioneered various strategies for the promotion of African Americans. It was the first Black Church created not to perpetuate a system of inhumane superiority but instead to spiritually liberate African Americans. It was the first to create the Christian Recorder, the first Black Newspaper. The newspaper kept Blacks informed about their Christian duties, updates, and opportunities that proved to be beneficial. They are now the first to partner with the presidents of nineteen Black banks in the United States. The goal of the partnership is to increase the wealth in the Black community. Similar to freedom, education has meant many things throughout Black history. Today, education means teaching Blacks how to use their acquired high school and college education in order to be financially successful.

Black Wealth 2020 is an organization that is making systematic efforts to teach Blacks about wealth building and economic self-sufficiency. Marie Johns, chair of the Howard University board of visitors and creators of SBA's Council on Underserved Communities says, "that being the importance of supporting Black banks, the importance of homeownership, the importance of growing Black businesses - those really are the three pillars of economic empowerment," states Marie Johns. ${ }^{162}$ She also describes the

\footnotetext{
162 Black Wealth 2020: New Economic Justice Movement Aims to 'Turbo Charge' Black Wealth in America
} 
importance of these three pillars associating them with a concept of freedom. The focus of the organization is on the financial plight of Black people. By incorporating this threepronged approach it is essentially preparing the Black community to be self-sufficient with an economy of its very own. Planting and harvesting these economic seeds are hoped to close the economic disparities between Blacks and whites. With over 6,000 AMECs in the continental United States, the partnership between the church and the economic organization seems promising. Black Wealth 2020 has a shared leadership that is comprised of individuals that work in elite universities, government positions, banking and financing associations and several non-profit organizations. The leadership is robust in various types of knowledge that can be very impactful for the Black community. The partnering of the AMEC with this secular organization is practical and aligned with the church's historical and contemporary aspirations. If AMEC leaders are being educated by members that are well-informed about the current economic conditions of America's Black community and have the skill set to provide solutions to those conditions then the congregation itself is being led in the direction of betterment. It is in this way that the church's concept of education has evolved. It includes more than liberal arts and technical training. It also includes concepts regarding financial freedom. The partnership between Black Wealth 2020 and the AMEC illustrates how even now in 2019 the religious institution is still socially intervening and reforming on behalf of its community.

\section{Economic Education}

The concept of economic salvation is not new. However, the church is focusing on it much more than it was in the $18^{\text {th }}, 19^{\text {th }}$, and early $20^{\text {th }}$ century. Once it became 
evident that a high school and college education was not going to be enough, the church has been adamantly working to ensure that the Black community is receiving that level of education but also a different and equally necessary one. Thirty-seven years ago in 1982, the New York Times published an article entitled "Black Churches Forging Coalition to Battle Economic and social Ills". The article states that there was "a coalition of the seven largest Black denominations, called the Congress of National Black Churches." 163 Bishop John Hurst Adams of the AMEC established the organization. He established interdenominational dialogue within the African American community, which led to the facilitation of collective church action. Amongst the coalition of the seven Black denominations are: the AMEC; African Methodist Episcopal Zion; Christian Methodist Episcopal; Church of God in Christ; National Baptist Conventions of America, Inc.; the National Baptist Convention, USA, Inc.; National Missionary Baptist Convention of America; and Progressive National Baptist Convention, Inc. What is particularly interesting about this organization is how they planned to liberate Blacks from their economic ailments. By educating Black ministers in business management they would then have the tools in order to lead their congregations. With this education instilled inside of the leadership it would ultimately be transmitted to the congregation, both adults and youth, and would eventually break the cycle of economic instability due to lack of knowledge. This mirrors the partnership between AMECs today with Black Wealth 2020. They both have similar aims, namely the imparting of an economic-focused education to the leadership that would trickle down to the laity. In 1982, Dr. Lawrence Jones, who was

${ }^{163}$ Briggs, Kenneth A. "Black Churches Forging Coalition to Battle Economic and Social Ills." The New York Times. December 12, 1982. 
a longtime minister, religious administrator, and dean of the Divinity School of Howard University, stated "Howard University would soon introduce such a course for theological students, and a combined degree program for master of business administration and master of divinity." 164 Thirty-seven years later, Howard University now offers a Master of Divinity/Master of Business Administration. The degree program is innovative in the sense that it provides religious leaders with a multifaceted skill set. According to Howard University School of Divinity, the program is "tailored to meet the needs of today's leaders who wish to gain a strong theological education and management education to enhance their effectiveness in ministry, business, non-profit, and public sector careers". ${ }^{165}$ The courses offered are theological studies, biblical studies, and ministry studies just to name a few. But the program also requires students to take financial accounting, financial management, strategic management, and macroeconomics for Business. These are just a few of the courses that the program requires its students to take but they are being listed because the titles offer a great deal of information. These courses ensure that graduates from the program are well rounded and equipped to perform their tasks as modern day religious leaders. The Black Church has always been an institution that not only met religious and spiritual needs but secular needs as well. As the church developed and the needs of the Black community became more nuanced so did the role of its religious leaders. Therefore, the divinity program originally proposed by the late Dr. Jones was both forward thinking and necessary. This

\footnotetext{
${ }^{164}$ Black Wealth 2020: New Economic Justice Movement Aims to 'Turbo Charge' Black Wealth in America

${ }^{165}$ Howard School of Divinity
} 
is one way that the Congress of National Black Churches hoped to educate its congregation through its religious leaders. By preparing the leadership, using a top-down approach, ministers are regarded as the teachers that are meant to teach and deliver crème de la crème education to their congregation. There's another resemblance in the efforts of the AMECs in 1982 and 2019; the church supported the partnership between the Black Church and business leaders to assist in defining economic plans that would prove useful for the Black community. In each case, the leadership is further educated by individuals that specialize in business and finances and then imparts that knowledge to the members of the church. The organization remains active in the $21^{\text {st }}$ century; there is a board of directors consisting of four representatives from each denomination and they meet twice a year. There is also a staff of approximately 20 people, as well as an executive director, who ensures that various policies are implemented and that the organization remains active on a daily basis. The organization has had several effects on the Black community. It has provided moral leadership for the Black community and also has operated as a social service agency. It has assisted the poor and encouraged the development of the Black ministry by holding seminars and awarding fellowships to those individuals interested in ministry. Additionally, it has initiated an Anti-Drug Campaign. Lastly, it has discussed ways to provide health insurance. The AMEC constantly depicts its energized concept of social intervention through its active engagement in bettering its community's socio-economic situation. The institution has always championed education as a catalyst to this sentiment; however, its focus has widened to encompass practical knowledge regarding financial success. 


\section{CONCLUSION}

This final chapter highlights the premise on which this thesis has been established: that the contemporary AMEC is just as active in advancing Blacks socioeconomic position in American society as its historical self. It also provides a summary of the main findings and the contemporary approach of the AMEC in regards to Blacks' economic ailments in the 21 st century.

\section{The Premise of the Thesis}

From the 18th century to the 21 st century the AMEC has stood as both a religious and social institution for the Black community, supporting it in its advancement. In each century, the AMEC has played a paramount role in assisting African Americans in positioning and defining their equal role and citizenship in the American society, all the while remaining spiritually devoted. Salvation and elevation are two important themes to the AMEC and the Black community. Salvation denotes religious deliverance while elevation signifies secular advancement. Both themes were significant and this is exemplified through the works of the AMEC religious leaders such as Richard Allen, Daniel Payne, and Richard Robert Wright Jr. Moreover, the AMEC's keenness to social advancement is demonstrated through its establishments of innumerable schools, mutual 
aid societies, and economic initiatives in order to provide the Black community with a religion that they can identify with and a religion that had practical implications.

In the late 18th century and early 19th century, while Richard Allen was the bishop, the AMEC was focused on achieving a rudimentary education that would provide African Americans with the necessary skill set in order to be effective and devout Christians. While Allen was bishop of the AMEC, he sought to provide African Americans with an environment where they could worship freely and outwardly without the oppressive treatment of White Americans. He achieved this by establishing the AMEC and subsequently provided the Black community with religious autonomy. A basic education became even more important, especially acquiring the ability to read. If African Americans hoped to remain autonomous they would need to learn to read so that they may be effective ministers to their congregants and have basic computational skills for daily economic affairs. The importance of education became more evident with the purchasing of the first AMEC.

In the mid 19th century, Daniel Payne honed in on the importance of education and made a direct correlation between Black advancement and education; furthermore, he was the first bishop to realize and vocalize the role that the AMEC had to play in the grand scheme of it all. It was with Bishop Payne that education began to be conceptualized in more than a religious context, but also within a socioeconomic context as well. While Richard Allen focused on providing the Black community with a place to worship free from discrimination and education was thought of religiously; Daniel Payne attention was placed on the establishment of schools and education, for Payne, education was meant to be applicable to both religious and secular affairs. This is exemplified by 
the purchasing of Wilberforce University, which is the first college owned and operated by the AMEC. Payne purchased it and he was selected as the first African American to lead to a college when he became its president in 1856 . Wilberforce University provided a diverse range of courses but it primarily concentrated on a liberal arts education, which was meant to empower Blacks and instill within them a broad knowledge set and transferrable skills. W.E.B. Du Bois was a proponent of this type of education. The college also offered an industrial education program; this program has had an approach to learning from an industry perspective and traditional subjects were taught within the context of the specific field. Booker T. Washington was an advocate for industrial education.

In the 19th century, the major question was: what is the most effective educational approach for the African American community. The debate between Booker T.

Washington and W.E.B. Du Bois was at the foundation of the question and the differing views between the two had a direct effect on the AMEC and the programs it offered at its colleges.

Richard R. Wright stood firmly in the middle of the two educational ideologies and actively worked to maintain both approaches during his presidency over Wilberforce University. As bishop of the AMEC, he advocated for education as a means to advance African Americans plight, in a way similar to that of Daniel Payne. He too recognized the power innate in education and the connection it had to socioeconomic advancement. In many ways, Wright was able to merge the philosophies of Payne, Washington, and Du Bois in such a way that his religious approach was the most practical out of all of the bishops from the 18th century to the 20th century. Partly due to his observance of the 
social gospel and his desire to develop and offer African Americans real opportunities such as the establishment of the Eight Ward Settlement Bank and advocating for both an industrial and liberal education. The objective of most of the programs and initiatives promoted by Wright were to elevate the Black community.

While education remains important, the hoped-for economic development remains elusive. In the 21st century, African Americans are increasingly attaining higher levels of education and degrees. Though there remains an imbalance between the amount of education acquired and the generating of wealth. In order to combat this modern predicament, the AMEC is developing new initiatives and business relationships to propel the Black community. This creates the impression that the AMEC is constantly evolving so that it can be an effective religious and social institution for the Black community. The objective of this project was to trace the evolution of the AMEC to determine if the contemporary church is as impactful as the historical AMEC.

\section{Findings}

In-depth research has proven that the AMEC is just as actively engaged in social reform activities as they were historically. African American churches were and still are the center of Black life; the Black Church was and continues to be active in the Black struggle. Some scholars postulate that the Black Church was a post-slavery institute. On the contrary, scholars such as Franklin Frazier and others understand that the Black Church began its operation before the ending of slavery. In some cases, it functioned as 'an invisible institute' and in others it blatantly liberated its Black congregation and its surrounding community. Prior to the Emancipation Proclamation, the first AMEC, Bethel 
Church, was opened in 1816. That's forty-seven years before the emancipation of African Americans in 1863. The church also housed the first school for Blacks in America prior to Blacks' release from bondage. Being influenced by its mother church, the Methodist Church, the AMEC prided itself on establishing educational institutions that would prove to be benevolent to the new citizens of America. The Methodist Church was amongst the first churches to establish societies to aid the newly freedmen. The purpose of the organization was to assist Blacks in integrating into mainstream society; it also had a purpose to educate. The Methodists also established schools for Blacks. Despite theological and social differences, the AMEC witnessed firsthand what it meant to be a religious institute that was also seeking solutions to the problems of the world. It is from this that the AMEC observed, adopted, and then adapted some of the practices of the Methodist Episcopal Church. In the same way that the Methodist Episcopal Church withdrew from the commission so that they may directly assist African Americans in obtaining a practical education, the AMEC withdraw from the Methodist Episcopal Church in order to do the same, but on a larger scale. Throughout AMEC's history, the term freedom has had a direct impact on the energy exertion of the Church, inspiring it to be more for the Black community than just a house of prayer. This was exemplified when the first AMEC aspired to provide both spiritual and secular guidance — giving religious instruction and offering a day school for children where they could learn to read and write. Tracing the different socio-economic initiatives of the AMEC through the lenses of education from the late 18th century to the present has revealed the various meanings attached to the term freedom, but more importantly how the church has adapted and evolved to acquire it. 
During the antebellum period, the time before the Civil War when slavery still ran rampant, freedom meant literal release from bondage. During this time AMEC leaders incorporated various methods to give African Americans freedom and solace from the oppressive forces of bondage. When Richard Allen founded the AMEC it was due to a disconnect between the true gospel and the manner in which Methodists were practicing it. Though not yet termed liberation theology, Allen pioneered a type of Christianity that mirrored what we now call liberation theology. Liberation theology is a movement in Christian theology that emphasizes liberation from social, political, and economic oppression as anticipation of ultimate salvation. By founding the AMEC, Allen created a house where African Americans were free to worship without discrimination.

Furthermore, it gave them a place where they could learn the gospel but also how to read and write. The leaders of AMEC believed that education would assist with many of the discriminatory problems that African Americans encountered and in the 1854 Baltimore Conference discussed establishing literary institutions and the expansion of educational efforts. In the 1850s, the AMEC established several educational facilities such as libraries, common schools, and various other learning institutions. Most monumental was the establishment of the Church's first historically Black college, Wilberforce University, opened in 1856. During the antebellum period, the AMEC believed that it was crucial that the church focused on the immediate needs of the community. One primary focus on the church during this time was ensuring that Blacks had an elementary education and were literate. Many of the colleges during this time considered themselves to be colleges, however, the instruction was primarily elementary in nature. This is not exclusive to historically Black colleges. The process of receiving and granting accreditation has been 
a long one. Though African Americans were enslaved during this time period, the AMEC leaders provided them with an environment where they could momentarily escape the pressures associated with bondage while simultaneously preparing them for their literal release.

Immediately after the antebellum period, once Emancipation had finally arrived, freedom meant the right to be educated, employed, and to move about freely from place to place. Only a year after the Civil War, the AMEC already owned and operated eleven colleges and normal schools with more than 2,000 students. Founding learning institutions ensured that education was easily accessible to Blacks, which increased the likelihood of them acquiring an education, which ultimately increased the number of job opportunities available to them. This particular time period, in regards to education and socio-economic mobility, differed from the antebellum period. There was less of a focus on elementary education and basic literacy. Elementary education and literacy were of immediate need during the antebellum time period and though the church was still focused on immediate relief, its eyes were set on long-term relief as well. There was an understanding that industrial jobs were of instant use, but preparing students solely for this type of work was not an interest of the AMEC. In many ways, the AMEC colleges differed from other historically Black colleges. Its educational approach prepared Blacks for the moment when they would become leaders in American society. Institutes such as Tuskegee Institute and other industrial schools focused primarily on an industrial curriculum, whereas, the industrial curriculum took a secondary role in the AMECs' educational institutes. The AMEC enlightened its students with a classical and liberal arts education first, and an industrial education second. It is also important to state that the 
individuals responsible for educating the Black community were Black themselves and therefore the opening of the many institutions provided jobs in of itself. This increase of educational facilities led to an increase in employment and the focus on a classical and liberal education opened the minds of many Blacks and prepared them for their role as American citizens. The AMEC was establishing these institutes when the government was unwilling to do so. The government did not provide free education to Blacks until well into the 20th century. It is because of the AMEC, amongst other churches such as the Methodist Episcopal Church, that African Americans were able to acquire an education and subsequently better their overall socio-economic position.

In the 20th and the 21st century, freedom meant and means social, political, and economic justice. From 1909-1928, AMEC Pastor Richard Wright Jr. partnered with his father to found a successful Black-owned bank, which offered real opportunities for African Americans. His ambition has affected modern AMEC leaders. The partnership between Black Wealth 2020 and the AMEC exemplifies the profound impact that Wright continues to have. Black wealth 2020 has a three-prong goal: one of them is to increase the number of deposits into Black Banks. Increasing the number of deposits that Blacks put into Black banks directly effects their economic and social position in American society. Fifty years after the federal Fair Housing Act banned racial discrimination in lending, African Americans continue to be routinely denied conventional mortgage loans at rates far higher than their white counterparts. This is true when it comes to receiving loans for businesses as well. Without a chance at homeownership or owning a business, African Americans are ultimately being discriminated against which counters the AMEC mission. Black banks can confront this vicious pattern by loaning to the Black 
community to increase the percentage of Blacks that own homes and businesses. This increase will help African Americans achieve economic and social justice in America, essentially achieving the AMEC's goal of liberation. Partnering with Black Wealth 2020 is only one example of the AMECs inclination to socially intervene on behalf of its community. In addition to partnering with financial experts, the AMEC has used data to develop a strategy to help them improve the churches' and its members' economic predicament. Strategies have also been developed to improve the quality of education that its colleges offer.

Findings suggest that the AMEC remains active in the Black community and continues to take measures to ensure its socio-economic betterment. In each time period, the AMEC has developed innovative programs and strategies to provide Blacks with the necessary skill set to be successful in the game of life, even though the odds were never in their favor. Findings indicate that the church has successfully adapted to meet the contemporary needs of the African American community; though there still remains a need for an economic program that directly educates African Americans on financial issues and successes such as homeownership, acquiring a business, and the importance of saving and investing. 


\section{BIBLIOGRAPHY}

A.G.B. "Thoughts - No. 1." The Colored American 1, no. 3 (July 4, 1840): 2.

A.G.B. “Thoughts - No. IX.” The Colored American 2, no. 1 (March 6, 1841): 2.

African Methodist Episcopal Church. "Quadrennial Address of the Bishops of the A.M.E. Church to the General Conference of 1864." Nypl.org. Accessed January 19, 2019. https://www.nypl.org/research/collections/shared-collectioncatalog/bib/b16337288.

African Methodist Episcopal Church, Richard Allen, Daniel Coker, and James Champion. $\quad$ 1817. The doctrines and discipline of the African Methodist Episcopal Church. Philadelphia: Published by Richard Allen and and Jacob Tapsico for the African Methodist connection in the United States. John H. Cunningham, printer.

Alexander, E. Curtis. Richard Allen: The First Exemplar of African American Education. New York: ECA Associates, 1985.

AME Church. "Strategic Plan." AME Church. Accessed January 19, 2019. https://www.ame church.com/news/strategic-plan/.

Anderson, James. The Education of Blacks in the South, 1860-1935. Chapel Hill: University of North Carolina Press, 1988.

B., Du Bois W. E., and David Levering Lewis. Black Reconstruction in America. New York: Atheneum, 1992.

Banner-Haley, Charles Pete T. To Do Good and to Do Well: Middle Class Blacks and the Depression, Philadelphia, 1929-1941. New York: Garland, 1993.

Berryman, Phillip. Liberation Theology. Philadelphia, PA: Temple University Press, 1987. 
Bialik, Kristen. "5 Facts about Blacks in the U.S." Pew Research Center. February 22, 2018.

Accessed January 18, 2019. http://www.pewresearch.org/fact-tank/2018/02/22/5facts

About-blacks-in-the-u-s/.

Billingsley, Andrew. Mighty like a River: The Black Church and Social Reform. New York:

Oxford University Press, 2003.

"Black Wealth | Black Wealth 2020." Black Wealth | Black Wealth 2020. Accessed January 19， 2019. https://www.blackwealth2020.com/.

Brawley, James P. Two Centuries of Methodist Concern: Bondage, Freedom, and Education of Black People. New York: Vantage Press, 1974.

Briggs, Kenneth A. "BLACK CHURCHES FORGING COALITION TO BATTLE ECONOMIC AND SOCIAL ILLS." The New York Times. December 12, 1982. Accessed April 01, 2019. https://www.nytimes.com/1982/12/12/us/blackchurches-forging-coalition-to-battle-economic-and-social-ills.html.

Butler-Mokoro, Shannon. Racial Uplift and Self-Determination: The African Methodist Episcopal Church and its Pursuit of Higher Education, 2010 http://ezproxy.fiu.edu/login?url=https://search-proquest com.ezproxy.fiu.edu/docview/898323826?accountid=10901.

Cameron, Richard Morgan. Methodism and Society in Historical Perspective. Nashville, Tennessee: Abingdon Press, 1961.

Childs, David J. "The Black Church and African American Education: The African Methodist Episcopal Church Educating for Liberation, 1816-1893." PhD diss., 2009.

Cook, Lindsey. "U.S. Education: Still Separate and Unequal." U.S. News \& World Report.January 28, 2015. Accessed January 17, 2019. https://www.usnews.com/news/blogs/data mine/2015/01/28/us-education-still-separateand-unequal.

Davie, Maurice R. Negroes in American Society. New York: McGraw-Hill, 1949.

"Demographic Trends and Economic Well-being." Pew Research Center's Social \& Demographic Trends Project. July 25, 2016. Accessed January 17, 2019. http://www.pewsocialtrends.org/2016/06/27/1-demographic-trends-and-economic-wellbeing/. 
"Digest of Education Statistics, 2017." National Center for Education Statistics (NCES)

Home Page, a Part of the U.S. Department of Education. Accessed January 19, 2019. https://nces.ed.gov/programs/digest/d17/tables/dt17_104.20.asp.

Dortch, Timothy Aldwin. 1997. "The Development of Curriculum and Instruction at Wilberforce

University from 1941 to 1947." Order No. 9723584, The University of Akron. http://ezproxy.fiu.edu/login?url=https://search-proquestcom.ezproxy.fiu.edu/docview/304350561 ?accountid=10901.

DuBois, W.E.B. The Negro Problem. A Series of Articles by Representative American Negroes of To-day. Contributions by Booker T. Washington ... W. E. B. Dubois, P. L. Dunbar, C. W. Chesnutt, and Others. New York: James Pott \&, 1903.

Flake, Floyd H., and Richard Allen. "The Religious, Social, Political and Economic American Development Ministry of Richard Allen: A Model for the 21st Century African 1994.

Church." PhD diss., United Theological Seminary, 1994. Abstract in November 1,

Freedmen's Aid Society. "Catalog Record: Annual Report of the Freedmen's Aid Society of the Methodist Episcopal Church." Catalog Record: Mineral Resources of Michigan With... Hathi Trust Digital Library. Accessed January 18, 2019. https://catalog.hathitrust.org/Record/011249312.

Fleming, George James, and Christian E. Burckel. Whos Who in Colored America, Supplement: An Illustrated Biographical Directory of Notable Living Persons of African Descent in the United States. New York: Christian E. Burckel \& Associates, 1950.

Gregg, Robert. Sparks from the Anvil of Oppression: Philadelphias African Methodists and

Southern Migrants, 1890-1940. Philadelphia: Temple University Press, 1993.

Hagerty, Barbara Bradley. "Black Liberation Theology, in Its Founder's Words." NPR. March 31, 2008. Accessed January 25, 2019.

https://www.npr.org/templates/story/story.php?storyId=89236116.

Haynes, Elizabeth Ross. The Black Boy of Atlanta. Boston: House of Edinboro, 1952.

Holy Bible: King James Version. Peabody, MA: Hendrickson Publishers, 2012.

Johnson, Sarah Coprich. The Role of the Black Church in Family Literacy. New York: P. Lang, 1999. 
Jones, Janelle, John Schmitt, and Valerie Wilson. "50 Years after the Kerner Commission: African Americans Are Better off in Many Ways but Are Still Disadvantaged by Racial Inequality." Economic Policy Institute. February 26, 2018. Accessed January 19, 2019. https://www.epi.org/publication/50-years-after-the-kernercommission/.

Joint Center for Housing Studies. "The State of the Nation's Housing 2018." The State of the Nation's Housing 2018 | Joint Center for Housing Studies of Harvard University. August 29, 2018. Accessed January 21, 2019. http://www.jchs.harvard.edu/search/?s=housing 2018.

Jost, Kenneth. "Black Colleges: Do They Still Have an Important Role?" CQ Researcher 13, no. 43 (December 12, 2003): 1045-68.

http://http://search.ebscohost.com/login.aspx?direct=true\&db=a9h\&AN=1199430

70\&si $=$ ehost-live\&scope $=$ site.

Kenney, Tanasia. "The A.M.E. Church and 19 Black-Owned Banks Team Up to Launch New Partnership for Longterm Black Wealth." GOOD BLACK NEWS. July 8, 2018. Accessed January 19, 2019. https://goodblacknews.org/tag/black-wealth-2020/.

Lincoln, Charles Eric., and Lawrence H. Mamiya. The Black Church in the African American Experience. Durham: Duke University Press, 2005.

Marte, Jonnelle. "'We Haven't Made Any Progress': Black Homeownership Is Stuck near 30-year Lows." The Washington Post. July 06, 2018. Accessed January 21, 2019. https://www.washingtonpost.com/business/economy/the-black-whiteemployment-gap has-closed-but-the-homeownership-gap-has-not-hereswhy/2018/07/06/1c6943dc-7ef6 11e8-b0ef-

fffcabeff946_story.html?noredirect=on\&utm_term=.b211a3552988.

McKernan, Signe-Mary, Caleb Quakenbush, Caroline Ratcliffe, Emma Kalish, and C. EugeneSteuerle. "1 Wealth Inequality Is Growing." Nine Charts about Wealth Inequality in America (Updated). October 04, 2017. Accessed January 19, 2019. https://apps.urban.org/features/wealth-inequality-charts/.

Meakin, Kate. "Richard R. Wright Sr. (1855-1947) • BlackPast." BlackPast. January 31, 2019.

Accessed March 22, 2019. https://www.blackpast.org/african-americanhistory/wright-richard-r-sr-1855-1947/.

Meier, August. Negro Thought in America: 1880-1915; Racial Ideologies in the Age of Booker T. Washington. Ann Arbor: Univ. of Michigan Press, 1969.

Millner, Darrell. "Blacks in Oregon." The Oregon Encyclopedia. October 1, 2018. Accessed

January 18, 2019. https://oregonencyclopedia.org/articles/blacks_in_oregon/\#.XEJES89KjUo. 
Minutes, Methodist Annual Conference, 1780, p.12.

Modesto, Kevin. "Won 't Be Weighted Down:" Richard R. Wright, Jr.'s Contributions to Social Work and Social Welfare." The Journal of Sociology \& Social Welfare, June 2004, 1-23.

https://scholarworks.wmich.edu/cgi/viewcontent.cgi?referer=https://www.google. com/ httpsredir $=1 \&$ article $=2984 \&$ context=jssw .

Payne, Daniel Alexander. Recollections of Seventy Years. Salem, NH: Ayer, 1991.

Payne, Daniel Alexander. History of the African Methodist Episcopal Church. North Stratford, NH: Ayer Pub., 2000.

Raboteau, Albert J. Slave Religion. New York City, New York: Oxford University Press, 2004.

"Related Information." Samuel Chapman Armstrong. Accessed March 16, 2019. http://www.hamptonu.edu/about/armstrong.cfm.

Sweet, William W. "The Methodist Episcopal Church and Reconstruction." Journal of the

Illinois State Historical Society (1908-1984) 7, no. 3 (1914): 147-65. http://www.jstor.org/stable/40194198.

US Census Bureau. "Census.gov." Census Bureau QuickFacts. Accessed January 19, 2019. https://www.census.gov/.

US Census Bureau. "Data." Census Bureau QuickFacts. August 28, 2018. Accessed January 19, 2019. https://www.census.gov/data/tables/time-series/demo/incomepoverty/historical income-households.html.

Usbc. "Black Wealth 2020: New Economic Justice Movement Aims to 'Turbo Charge' Black Wealth in America." US Black Chambers, Inc. Accessed January 21, 2019. http://www.usblackchamber.org/usbc-about-us/122-university/blog/397-blackwealth 2020-new-economic-justice-movement-aims-to-turbo-charge-blackwealth-in-america.

Wright, Richard R. 87 Years behind the Black Curtain: An Autobiography. Philadelphia: Rare Book, 1965.

Wright, Richard R. The Negro in Pennsylvania; a Study in Economic History. New York: Arno Press, 1969. 
Zimmerman, Constella Hines. "Contributions of the African Methodist Episcopal Church and its Leadership to Higher Education for Adult African-Americans during the Late Nineteenth Century: 1865-1890.” Ph.D. diss., Rutgers State University, 1998. 